Article

\title{
Evolution of Surface Hydrology in the Sahelo-Sudanian Strip: An Updated Review
}

\author{
Luc Descroix $^{1, *}$, Françoise Guichard ${ }^{2}$, Manuela Grippa ${ }^{3}$ iD, Laurent A. Lambert ${ }^{4}$ (iD, \\ Gérémy Panthou ${ }^{5}$ (D), Gil Mahé ${ }^{6}$ (D), Laetitia Gal ${ }^{3}$ (iD) , Cécile Dardel ${ }^{3}$, Guillaume Quantin ${ }^{5}$, \\ Laurent Kergoat $^{3}$, Yasmin Bouaïta ${ }^{1}$, Pierre Hiernaux ${ }^{3}$, Théo Vischel ${ }^{5}$, Thierry Pellarin ${ }^{5}$, \\ Bakary Faty ${ }^{7}$, Catherine Wilcox ${ }^{5}$, Moussa Malam Abdou ${ }^{8}$, Ibrahim Mamadou ${ }^{8}$, \\ Jean-Pierre Vandervaere ${ }^{5}$, Aïda Diongue-Niang ${ }^{9}$, Ousmane Ndiaye ${ }^{9}$, Youssouph Sané ${ }^{9}$, \\ Honoré Dacosta ${ }^{10}$, Marielle Gosset ${ }^{3}$, Claire Cassé ${ }^{3}$, Benjamin Sultan ${ }^{11}$, Aliou Barry ${ }^{12}$, \\ Okechukwu Amogu ${ }^{13}$ (D), Bernadette Nka Nnomo ${ }^{14}$, Alseny Barry ${ }^{15}$ and \\ Jean-Emmanuel Paturel ${ }^{6}$ ib
}

1 Unité Mixte de Recherche (UMR, Lab) Patrimoines Locaux et Gouvernance (PALOC) Institut de Recherche pour le Développement (IRD)/Muséum National d'Histoire Naturelle (MNHN), Laboratoire Mixte International (LMI) Patrimoines et Territoires de l'Eau(PATEO), IRD Hann, BP 1386, 18524 Dakar, Senegal; yasmin.bouaita@gmail.com

2 Centre National de Recherches Météorologiques (CNRM), UMR 3589, Centre National de la Recherche Scientifique (CNRS) / Météo-France, 31057 Toulouse, France; francoise.guichard@gmail.com

3 UMR Géosciences Environnement Toulouse (GET) CNRS/IRD, Observatoire Midi-Pyrénées (OMP), 31400 Toulouse, France; manuela.grippa@get.omp.eu (M.G.); laetitia.gal@ird.fr (L.G.); cecile.dardel@gmail.com (C.D.); laurent.kergoat@get.omp.eu (L.K.); pierre.hiernaux2@orange.fr (P.H.); marielle.gosset@ird.fr (M.G.); claire.casse@ird.fr (C.C.)

4 Social and Economic Survey Research Institute (SESRI), Qatar University, Al Dafna. P.O. Box 2713, Doha, Qatar; laurent.a.lambert@googlemail.com

5 Institut des Géosciences et Environnement (IGE) CNRS/IRD/Université Grenoble-Alpes (UGA)/Grenoble Institut National Polytechnique (GINP), Observatoire des Sciences de l'Univers de Grenoble (OSUG), 38400 Grenoble, France; geremy.panthou@univ-grenoble-alpes.fr (G.P.); guillaume.quantin@univ-grenoble-alpes.fr (G.Q.); theo.vischel@univ-grenoble-alpes.fr (T.V.); thierry.pellarin@univ-grenoble-alpes.fr (T.P.); catherine.wilcox@univ-grenoble-alpes.fr (C.W.); jean-pierre.vandervaere@univ-grenoble-alpes.fr (J.-P.V.)

6 UMR Hydro-Sciences Montpellier (HSM) IRD/Université de Montpellier (UM), 34000 Montpellier, France; gil.mahe@ird.fr (G.M.); jean-emmanuel.paturel@ird.fr (J.-E.P.)

7 Direction de la Gestion et de la Planification des Ressources en Eau (DGPRE), BP 14484, 18524 Dakar, Senegal; bakaryfaty@gmail.com

8 Department of Geography, Zinder University, BP 656, Zinder, Niger; moussa.malamabdou@gmail.com (M.M.A.); imadou_ib@yahoo.fr (I.M.)

9 Agence Nationale de l'Aviation Civile et de la Météorologie (ANACIM), BP 8184, 18524 Dakar, Senegal; aida.diongue.niang@gmail.com (A.D.-N.); ousmane.ndiaye@anacim.sn (O.N.); youssouph.sane@anacim.sn (Y.S.)

10 Department of Geography, Université Cheikh Anta Diop (UCAD), BP 5005, 18524 Dakar, Senegal; dacosta.honore@gmail.com

11 UMR ESPACE DEV IRD/Institut de Recherche des Sciences et Technologies de l'Environnement et de l'Agriculture (IRSTEA)/UM, 34000 Montpellier, France; benjamin.sultan@ird.fr

12 Direction Nationale de l'Hydraulique, BP 642, 999049 Conakry, Guinea; barryaliou55@yahoo.fr

13 Coyne et Bellier, Tractebel Engineering France, 92622 Gennevilliers, France; okeamogu@yahoo.com

14 Centre de Recherches Hydrologique (CRH) de l'Institut de Recherches Géologiques et Minières (IRGM), BP 4110 Nlongkak, 999108 Yaoundé, Cameroon; bnnomo@gmail.com

15 MEEF Ministère de l'Environnement des Eaux et Forêts/Ministry of Environment, Water and Forests, BP 761, 999049 Conakry, Guinea; alseny2barry@gmail.com

* Correspondence: luc.descroix@ird.fr; Tel.: +221-77-245-38-22 
Abstract: In the West African Sahel, two paradoxical hydrological behaviors have occurred during the last five decades. The first paradox was observed during the 1968-1990s 'Great Drought' period, during which runoff significantly increased. The second paradox appeared during the subsequent period of rainfall recovery (i.e., since the 1990s), during which the runoff coefficient continued to increase despite the general re-greening of the Sahel. This paper reviews and synthesizes the literature on the drivers of these paradoxical behaviors, focusing on recent works in the West African Sahelo/Sudanian strip, and upscaling the hydrological processes through an analysis of recent data from two representative areas of this region. This paper helps better determine the respective roles played by Land Use/Land Cover Changes (LULCC), the evolution of rainfall intensity and the occurrence of extreme rainfall events in these hydrological paradoxes. Both the literature review and recent data converge in indicating that the first Sahelian hydrological paradox was mostly driven by LULCC, while the second paradox has been caused by both LULCC and climate evolution, mainly the recent increase in rainfall intensity.

Keywords: Sahel; land use/land cover changes; water holding capacity; climate change; hydrological paradox; re-greening

\section{Introduction}

West Africa suffered a long rainfall deficit (often called the "Great Drought") during the second half of the 20th century [1] (from 1968 until the 1990s, with specific end dates varying throughout the area). During this Great Drought period, despite the lack of rainfall, an increase in Sahelian river discharge was observed [2-5]. This rise was later defined as the first "Sahelian hydrological paradox [6]".

The most severe rainfall deficit ever observed in West Africa lasted until 1993 in the central and eastern Sahel, and until 1998 in the western part of the sub-region [7]. More recent years have been more rainy, and observations indicate that mean annual rainfall from 2006-2015 is close to the 1900-2015 average [7]. Furthermore, the contrast observed by Ali and Lebel [8] and by Mahé and Paturel [9], between the central and eastern Sahel on the one hand, where a "recovery" of rainfall was observed, and the western Sahel still under deficit, seems to have vanished over the last decade.

The relative increase in annual rainfall levels since the very end of the 1990s, which reached the 1900-2015 average value, appears to be the main factor explaining the observed widespread re-greening trend over the Sahel, mostly in rural areas. Almost all remote -based vegetation maps demonstrate a dominant increase in NDVI signal since the early 1980s [10-16]. These studies did not always determine the respective contribution of the annual and perennial vegetation in this progression. However, most of the re-greening is probably due to herbaceous recovery, although there is also evidence of significant natural increase in tree cover over the last 15 years [15].

Since about 2005, an increase in runoff-both autogenic (yielded in place) and allogeneic (yielded upstream) - has been observed despite evidences of continuing re-greening. This raises questions about (i) the hydrological efficiency of the present vegetation cover and (ii) the contributions of other factors such as rainfall intensification and more local changes (e.g., the extension of catchments due to endorheism bursting). This increase in runoff, which has been occurring in parallel to re-greening, has recently been called the second "Sahelian paradox" [13]. Human and material losses due to floods clearly exceed those due to drought in recent decades, as summarized by [17] from observations in western Niger.

Although the main contributing areas for runoff yield are the rural ones, urban flooding events regularly impact communities, and cause severe damages to the built environment. It is important to distinguish between two kinds of urban flooding. The first one is due to the overflowing of large rivers, and is referred to as an "allogeneic" flood. The second kind of urban flooding, referred to as 
"autogenic" floods, is caused by flash floods induced by urbanization dynamics, more specifically by urban sprawl, increased soil imperviousness and, often, insufficient rain water drainage systems.

This increase in runoff during the rainfall deficit period was only observed in the Sahel, while the Sudanian strip has been showing a perhaps more predictable behavior, with streamflow decreasing two to three times more than rainfall [2,18-20].

This paper presents a synthesis of recent advances on the debate of whether rainfall pattern changes and land use and land cover changes (LULCC) is the main factor driving the recent hydrological behavior in the Sahel region. It aims at providing a better understanding of their respective role on the hydrological Sahelian paradoxes. Hereafter, we will consider LULCC, i.e., we will merge these two processes due to the similar hydrological changes that they cause in the basin's hydrological functioning.

More specifically, we present a synthesis of the rainfall and streamflow evolution in the Sahelo-Sudanian strip with updated rainfall data of Senegambia and the Middle Niger River Basin (MNRB). The Sudanian strip (and some parts of the Guinean region) is included in this analysis in order to compare both Sahelian and Sudanian regions.

After a description of data and methods (Section 2), we introduce in greater detail the two "Sahelian paradoxes" and the main Sahelian and Sudanian functioning (Section 3). An upscaling of these behaviors is presented in Section 4. The two following sections are dedicated to the analysis of the main explanatory variables of the regionalization: the LULCC, focusing both on vegetation degradation and the role of observed re-greening, on the one hand (Section 5), and the observed changes in rainfall, particularly its intensification and progressive recovery (Section 6), on the other.

\section{Material and Methods}

\subsection{Data}

\subsubsection{Hydrological Data}

We use data provided by the National Hydrological agencies of several countries (specifically Guinea, Burkina Faso, and Mauritania) and the Basin Authorities. Most of these data were collected since the time of installation of some stations by Orstom (now IRD Institut de Recherche pour le Développement) in 1944 to the early 1980s. The SIEREM system (Système d'Information Environnementale sur les Ressources en Eau et la Modélisation; IRD, HSM Hydro Sciences Montpellier lab, France) [21] collected and quality-controlled most of the available data in an open database, which also includes rainfall data. A few monthly mean data were reconstructed (only 16 months for the Bani River, 10 months for Upper Niger, 8 months for Milo River and 2 months for the Niandan River, within the 63 years observation period), predominantly from 1997 to 2012. In addition, there are 12 reconstituted months of data for the Dargol River, 4 months for the Sirba River and 2 months for the Gorouol River (in 57 years).

This data allowed us to estimate a yearly mean discharge and to generate a database of daily discharges of each river over 48 to 63 years, depending on the basin, without data gaps. Missing data were estimated, usually through interpolation, by accounting for the trends of three neighbor basins (or only two when it was not possible to have three). The reconstitution is then realized using the simple regression between two or three data sets. It is worth noting that the data of the Bakel station (Senegal River) were provided by Bader [21] who reconstructed the "natural stream flow" downstream of the Manantali dam built in 1988. Construction of the hydroelectric dam has changed the streamflow's responses to climatic variations, which can thereby change the significance of the statistical trends observed in the data [22]. Discharge evolution due to dams in Sections 3.3 and 3.4 are estimations based on official data of the NBA (Niger Basin Authority) and Office du Niger irrigated district. Table 1 describes the hydrological and rainfall data set and its sources. 
Table 1. Description of data set; top: rainfall data; bottom: runoff coefficient data.

\begin{tabular}{|c|c|c|c|c|}
\hline \multicolumn{3}{|l|}{ Country } & Time Span of Data & Source \\
\hline \multicolumn{3}{|c|}{ Benin, Burkina Faso, Mali, Mauritania, Niger, Togo, Senegal } & 1950-2012 & National Met Offices \\
\hline \multicolumn{3}{|c|}{ Chad, Ghana, Guinea, Nigeria, Cameroon } & 1950-1979 & SIEREM [23], Nat Met of \\
\hline \multicolumn{3}{|l|}{ Chad, Ghana, Guinea, Nigeria } & $1981-2010$ & CHIRPS [24] \\
\hline Basin & Time Span of Data & Missing & Reconstituted & Source \\
\hline $\begin{array}{l}\text { Alibori, Bani, Benue, Dargol, Diamangou, Goroubi, } \\
\text { Gorouol, Mekrou, Niger-Koulikoro, Niger-Niamey, } \\
\text { Sota, Tapoa }\end{array}$ & 1950-2012 & Numerous gaps & No reconstitution & NBA Niger Basin Authority \\
\hline Milo, Upper Niger, Niandan & 1950-2012 & 4 years & 10 months & Nat Hydrol. Service Guinea \\
\hline Ouémé & 1952-2012 & / & / & Nat Hydrol. Service Benin \\
\hline Bafing, Bakoye, Faleme, Senegal & 1950-2012 & / & / & OMVS (Senegal Basin Authority) \\
\hline Gambia, Koulountou & 1950-2005 & / & / & OMVG (Gambia basin authority) \\
\hline Chari, Logone, Mayo Tsanaga & $1950-2012$ & / & / & CBLT (Chad Lake basin Author) \\
\hline Nakanbé, Volta & 1965-2008 & 3 years & No reconstitution & VBA (Volta Basin Authority) \\
\hline Ankobra, Bra, Pia, Tano & 1951-1991 & 1 & $1 / 20$ & Opoku et al. [25] \\
\hline Gorgol el Abiod, Gorgol al Akhdar, Sokoto & 1958-1985 & 5 years & / & Mahé et al. $[9,26]$ \\
\hline Komadugu Yobe & 1950-2005 & Numerous gaps & No reconstitution & Genthon (personal communication) \\
\hline Mono, Couffo & 1961-2000 & / 01 & / & Amoussou et al. [27] \\
\hline $\begin{array}{l}\text { Bougouribga, Diaguiri, Goudebo, Niokolo Koba, } \\
\text { Mouhoun, Noaho, Tene, Upper Faleme, Upper } \\
\text { Gambia, Upper Gorouol }\end{array}$ & 1970-2006 & Numerous gaps & No reconstitution & Nka et al. [3] \\
\hline Upper Bandama & 1950-2000 & / & / & Soro et al. [28] \\
\hline
\end{tabular}


2.1.2. Rainfall Data and Processing Analysis

- $\quad$ Most of the rainfall data are provided by National Meteorological Offices (Table 1).

- However, for three areas, we used the Climate Hazards Group InfraRed Precipitation with Station (CHIRPS) data set [24]. This data set, which contains information from 1981 until just before the present, is an initiative of the U.S. Geological Survey (USGS) and the Climate Hazard Group (CHG), and is supported by several U.S. state institutions. It incorporates $0.05^{\circ}$ resolution satellite imagery with in situ station data to create gridded rainfall time series for trend analysis. This data set was already used in several works, including in Africa [29-31].

- The long-term rainfall evolution index in Section 6.2 is simply built with the $\%$ of annual variation vs. the mean value.

- Trends and breaks in the annual rainfall and runoff coefficient series were determined through the following processes: determination of breaks and trends by the rank method and the Lee and Heghinian, Pettitt, Buishand principles, and finally the Hubert segmentation; all are processed using the Khronostat ${ }^{\circledR} 1.01$ software of IRD [32].

- Analysis of daily rainfall is conducted in two areas: Senegambia and the Middle Niger River Basin (MNRB). In each one of the areas, a dozen raingauges are considered for the 1951-2015 period. They are homogeneously distributed in space; regionalization was processed using Thiessen polygons. Only the Menaka station (destroyed in 2013) presents data gaps.

\subsubsection{Land Use/Land Cover Changes (LULCC)}

Overall, LULCC are characterized by greening, which is strongly linked to vegetation production. Two maps synthesizing the information were built in the more relevant and regional covering references published in recent years [10-14,33,34]. The maps are the synthesis of six sources documenting changes in NDVI metrics assessing annual vegetation production through the Sahelian strip [10,12-14,33,34]. For each source, the areas of increasing (vs. decreasing) NDVI (Normalized Difference Vegetation Index) are mapped.

\subsection{Methods of Hydrological Processes Upscaling and Synthesis}

\subsubsection{Trend of Runoff Coefficient}

First, we map the evolution of the yearly runoff coefficient for all the basins where data were available in literature for at least 40 years. The runoff coefficient relates the annual runoff depth to the annual rainfall depth and is hereafter expressed as a percentage.

\subsubsection{Comparison of Hydrographs}

In a second step, we superpose the rivers' long term hydrographs (i.e., the annual mean discharge evolution curve) and classify them into "behavior" classes.

\subsubsection{Principal Component Analysis (PCA)}

Finally, a PCA is applied to the matrix of a set of basin's main data, in order to classify the main driving factors of the hydrological functioning. The considered variables are listed in Table 2. 
Table 2. List of the variables used in the PCA analysis of the factors explaining the hydrological functioning of West African basins.

\begin{tabular}{cl}
\hline Number & \\
\hline 1 & basin area \\
2 & Mean annual rainfall (MAR) 1950-2012 \\
3 & \% of rainfall decrease during drought period: MAR 1968-1993/MAR 1950-1967 \\
4 & \% of rainfall recovery after drought MAR 1994-2012/MAR 1968-1993 \\
5 & Time elapsed between rainfall break (1967 for all the basins) and discharge break (varying \\
6 & from 1967 to 1981 depending on the basin) \\
7 & \%ean annual discharge (1950-2012) \\
8 & \% discharge evolution during the drought (1968-1993)/the previous period (1950-1967) \\
9 & Time elapsed between the rainfall break (1967) and the RC (runoff coefficient) break \\
10 & Mean annual RC before break (1950-1967) \\
11 & \% RC evolution during drought (RC 1968-1993/RC 1950-1967) \\
12 & \% RC evolution after drought (RC 1994-2012/RC 1968-1993) \\
\hline
\end{tabular}

\section{3. "Sahelian Paradoxes" and Flooding Occurrence: Recent Advances in the Understanding of Sahelian and Sudanian Hydro Climatology}

An ongoing upward trend in the occurrence of inundations was highlighted in recent years in southern Sudanian areas [35], as well as in Sahelian regions [36]. In Africa, flood related fatalities and associated economic losses have increased considerably over the past half century, and this trend, which is also related to urbanization dynamics, is expected to have direct consequences on the population [37]. This increase in flood related fatalities and economic losses may be due to an increase in inundations, but also potentially to an increase in exposure and vulnerability, as suggested by Aich et al. (2016) [38]. The results of Paeth et al. [39] and Lafore et al. [40] also suggest that many factors, from synoptic-scale to large-scale circulations, including regional features and teleconnection patterns, contribute to the extremeness of the rainfall events that lead to flooding.

\subsection{A Marked Increase in Runoff Coefficients and Discharges of Sahelian Rivers}

The annual rainfall index was higher from 1950 to 1967, before a long deficit period from 1968 to 1991 in the three Sahelian tributary Rivers basins of the Niger River (Gorouol, Dargol and Sirba Rivers) as well as in all the other Sahelian Rivers. However, as shown below (Section 4), the runoff coefficients over the watershed of these rivers have continuously increased since the 1950s. This was paradoxical during the great drought period and it remains partially paradoxical due to the current runoff coefficient being four or five times higher than during the "wet 1957-1967 period", while rainfall annual amount remains significantly lower.

In the same South West region of Niger, Leblanc et al. [41] showed that the 1950-1992 land clearing period coincides with a strong increase in drainage density and an appearance of new ponds. This is due to a long term increase in surface runoff production, which shows that less rainfall does not necessarily imply less water erosion and runoff.

As shown above, in Sahelian areas, the decrease in rainfall was accompanied by a significant increase in runoff. The increase in runoff despite the drought is a process observed across the entire Sahel since the end of the 1960s. It motivated its designation as "hydrological Sahelian paradox". It was first observed in small experimental catchments of Burkina Faso [18], then in several West African basins [41], and in the Niger River basin [20,42,43]. Shortly later, this paradox was also observed on the right bank tributaries of the Niger River [19,44], and in the basin of Nakanbé in Burkina Faso [43,45]. Mahé et al. [9,46] also observed this paradoxical behavior westward in the two Gorgol Rivers basins of Mauritania [9], then eastward in the Sahelian Sokoto basin in the Sahelian part of Nigeria [46]. It must be noted that in Mauritania, a recent study [47] showed that the nomad population of the Sahelian part of the country left the rural areas to reach major urban areas at a very impressive rate: from $75 \%$ 
of the total population in 1965 , the rural population decreased to $12 \%$ in 1988 and only $6 \%$ in 2000 . This relative reduction of the rural population did not prevent the runoff coefficient from increasing in all the river basins during the end of the 70's and the 80's [9].

In the rangelands of north Sahelian area, Gardelle et al. [48] observed a strong increase in ponds and lake areas, which is linked to the increase in runoff. For the Agoufou watershed (Mali), runoff coefficients increased from about $\%$ to about $5.5 \%$ between 1965 and 2015 [49]. A similar behavior was found in two other watersheds in Mauritania (Hodj region) and Niger (Zinder region). The causes of this increase lie in the non-recovery of vegetation growing on shallow soils (woody and herbaceous) after the important rainfall deficit of the 70s and 80s that resulted in enhanced runoff, erosion, and drainage network development (shift from sheet runoff to rill and gully runoff) and soil erosion. In turn, this dynamics deprived vegetation from water and nutriments [50].

This hydrological paradox is strictly Sahelian $[2,6,7,9,26,45,46,51]$.

Paturel et al. [52] and Amani and Paturel [53] pointed out the necessary changes to be processed in hydrological regional norms in order to supply engineers with actual figures of rainfall and runoff characteristics, and new methods, able to account for the non-stationarity in hydrological variables.

The area of the MNRB (Figure 1a,b) is one of the most studied in the West African Sahel because it is the major exorheic basin of the whole western and central Sahel, and because it includes long term stream-gauges stations. In the same MNRB, Cassé et al. [54] observed that the Upper Niger contribution has followed the climatic trend, and inversely, that "the local runoff contribution has been continuously increasing over the 1953-2012 period, which is paradoxical given the rainfall signal" ([54], p. 2853). The opposite evolution between upstream and downstream signals results in the progressive increase of the "red" flood since the 1980s.

\subsection{A Reduced Lag Time, an Earlier Occurrence of Annual Flood}

Amani and Nguetora [44] observed in the Sirba River Basin between the 1960s and the 1980s that annual flooding occurred earlier in the later decade. The Sirba is a Sahelian tributary of the Niger River (Figure 1a,b). Figure 2 shows the evolution of the mean hydrograph by decade in the Niger River, Niamey Station. As described by Descroix et al. (2012) [2], the Niger River has two flood peaks; the first one, termed the red or local flood, arises from local rainfall, during and immediately after the rainy season. The second flood, named the Guinean flood or "black flood", originates from precipitations in the Upper basin (Guinean Dorsale and the Fouta Djallon) during the same rainy season. This second flood is delayed by three or four months in arriving at the Niamey station, a delay that is related to its crossing of the Niger Inner Delta (NID in Figure 1a); this takes place at the end of November, in December and January of the following year [2]. Figure 2 shows that the first "local", "red", or "Sahelian" flood, is now occurring earlier. Specifically, it currently occurs 40 days earlier in Niamey, compared to its average date of occurrence in the 1950s. In turn, the major "black", or "Guinean", flood also occurs earlier and, overall, it finishes notably earlier (by 75 days); this is also observed in the Niger Inner Delta $[55,56]$. The double pattern of the annual flood has been more marked in recent decades. From 2011-2015, the red flood became earlier and more pronounced, although monsoon onset and rainfall have not changed significantly since the end of the 20th century. The monsoon onset occurred earlier than at present during the wet decades of the 1950s-60s, and later during the "great drought" of 1968-1995 [7]. The red flood has almost reached the volume of the great, black flood; the difference between the hydrographs of the wet 1951-1970 period and that of the 2011-2015 period indicates the consequent strong reduction in soil water holding capacity (WHC) of the Sahel since the pre-drought period. 


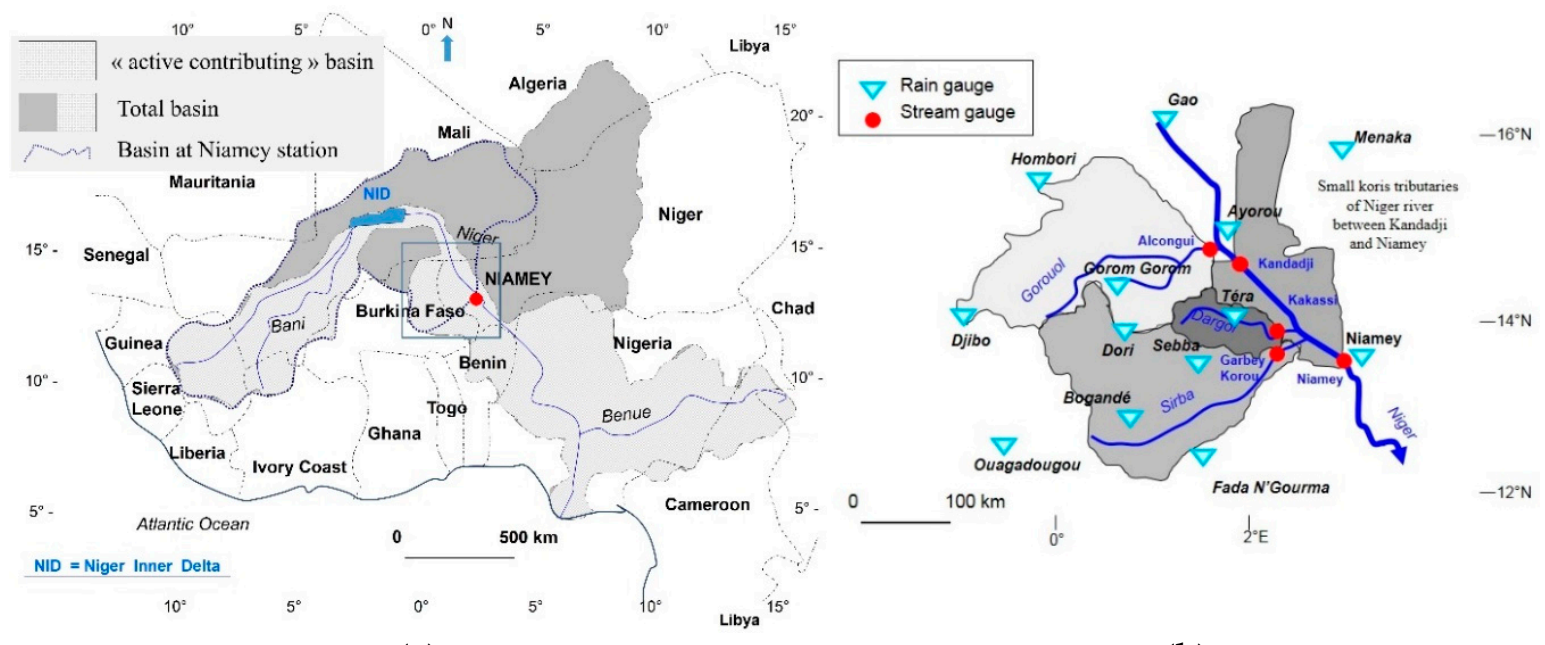

(a)

(b)

Figure 1. (a) Location of Middle Niger River Basin (MNRB); (b) topographical Gorouol, Dargol and Sirba basins with stream gauges and rain gauges location.

Although it is shorter than the other periods, the semi-decade of 2011-2015 could represent future MNRB behavior. The local Sahelian streams are flowing earlier and in increasing volumes due to the decrease in soil and landscape WHC. The Sudano-Guinean supply (the second flood) is increasingly separated, by a marked decrease in discharge, from the first one. It is also significantly shorter and smaller than during the wet decades of 1951-1970, as well as during the 2001-2010 decade, as a consequence of the observed pause in recovering rainfall in central Sahel and perhaps an increase in evaporation in the NID (Niger Inner Delta) due to the rising temperature.

\subsection{A More Intuitive Sudanian Functioning}

\subsubsection{The Sudanian Functioning at the Basin Scale}

The Sahelian paradox is strictly Sahelian. It is not observed in the Sudanian and Guinean areas, where, as perhaps more intuitively expected, the "great drought", although less marked than in Sahelian areas, led to a significant decrease in runoff coefficients. In the main rivers, the reduction in discharges was twice that observed for the annual rainfall amount.

\subsubsection{A Hewlettian Functioning at the Point and the Plot Scales}

The decreasing part of the Upper Niger basin in the total supplying stream flow of Niger River at Niamey station is the consequence of the mostly Hewlettian behavior of the Guinean and Sudanian basins, which preserved their soil and landscape WHC. Runoff decreased slightly at the beginning of the drought, due to the volume of natural water reservoirs; but during the 1980s, runoff was reduced by at least twice the equivalent in rainfall reduction $[2,19,20]$, because soils need to be filled before rainfall begins to cause runoff. Since the recovery of annual total rainfall, discharges have been increasing, but they are still far from pre-drought levels, due to the filling of the natural reservoirs. The filling of Selingue dam exaggerated the severe deficit at the beginning of the 1980s. 


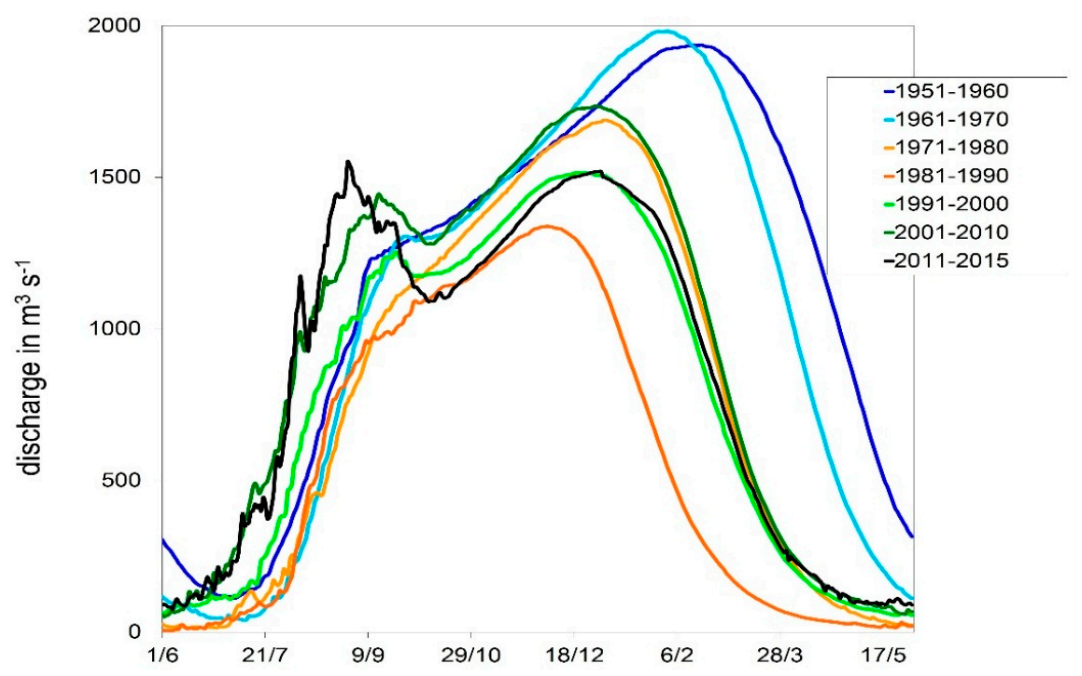

Figure 2. Decadal hydrographs of the Niger River at Niamey (x axis is time scale: $1 / 6$ is 1 June, $17 / 5$ is 17 May of the following year).

\subsubsection{Lake Chad as an Indicator of Drought}

The Lake Chad basin can be considered an integrative indicator of drought and hydrological processes of the Sudanian area. Water table and groundwater resources have been rising since the beginning of the dry period in the Western part of the Sahelian Iullemeden basin; numerous new ponds and lakes resulted from the increase in runoff coefficient, leading to a rise in groundwater recharge. Conversely, groundwater level has been diminishing as expected in the Chad basin due to decrease in the rivers discharges. The only Sahelian tributary of the Lake, the Komadugu-Yobe River, provides less than $5 \%$ of the total input to the lake. More than $95 \%$ of the input comes from Sudanian areas (mostly through the Logone and Chari Rivers), where discharges were severely reduced during the Great Drought. Since the beginning of the 1990s, however, annual inputs have increased, and it seems clear today that the existence of the lake is not threatened, as it appeared to be during the 1970s and 80 s $[57,58]$.

\subsubsection{Some Sudanian Rivers}

For some Sudanian tributaries of the Niger River, Badou et al. [59] determined that significant lower runoff was observed around 1979, followed by a regime shift to wetter conditions around 1992. In smaller basins, Nka et al. [3] identified only one case of a decreasing trend in flood magnitude in the long time series. They considered that the large sample of short time series used was stationary with respect to flood magnitude and occurrence; both were attributable to the evolution in mean rainfall since 1970. In some cases, Sudanian areas showed a "Sahelian" behavior characterized by increase in runoff due to WHC reduction: in the Dano River basin, in Sudanian area of Burkina Faso, Yira [60] estimated that during the period $1990-2013,2 \%$ of the catchment changed annually from natural and semi-natural vegetation to cropland. Since infiltration rates are 1.2 times higher on the former than on the latter, this led to an increase in total discharge of about $17 \%$ and a decrease of actual evapotranspiration of about $5 \%$. The authors also highlighted an increase of flood risk [60].

Slightly southward, in the Upper Bandama basin (Ivory Coast), a decrease of $16.5 \%$ in rainfall depths caused a $62 \%$ reduction in runoff at the Tortiya station during the 1970s and the 1980s [28].

\subsubsection{Guinean Rivers Have the Same Behavior}

In a more Southern (Guinean) area, closer to the Gulf of Guinea, Opoku-Ankomah et al. [25] showed that discharges during the dry season have been the most impacted by the rainfall reduction since 1970: the discharge exceeding $95 \%$ in the dry season dropped from 71 to $17 \mathrm{~m}^{3} \cdot \mathrm{s}^{-1}$ between the 
1951-1970 and the 1971-1990 periods, respectively. These results concern four small basins located in a coastal area with a sub-equatorial regime (with two rainy seasons) covering $23,000 \mathrm{~km}^{2}$ (the Bia, Tano, Ankobra and Pra Rivers basins; Figure 3), with annual rainfall amounts ranging from 1500 to $2000 \mathrm{~mm}$. In the Volta River basin, downstream from the Akosombo dam featuring one of the largest reservoir in the world, Oguntunde et al. [61] noticed that, between the 1931-1960 and the 1970-1998 periods, discharges of the Volta River decreased by $16 \%$, for a $10 \%$ reduction of rainfall in the whole basin. This trend matches with the Great Drought, but also with the dam building, and the creation of the Volta Lake, which constitutes a big evaporation pan. Therefore, the trend may result from distinct but probably complementary causes.

Based on observed data in the downstream reach of Niger River (at the entry of the Niger River Delta), a study by Itiveh and Bigg [62] highlighted a high correlation between precipitations on the whole Niger basin and discharge, without introducing any effect of land cover change. Their observations contradicted previous results obtained by modelling, such as those of Li et al. [63], which analyzed whether LULCC affected hydrological regimes at the basin scale for the Niger River and Lake Chad basins, and found that a total deforestation would lead to an increase in runoff coefficient from 0.15 to 0.44 .

\subsubsection{As a Conclusion, the Temporal Evolution of the Sudanian Hydrological Style}

Due to works of Albergel in Burkina Faso [18], it is well established that in Sudanian regions, at the scale of small experimental catchments, discharges decreased during the drought. This was confirmed by several studies during the 1990s [64,65], and then synthesized at a larger scale by Olivry [20] for the upper tributaries of the Niger River, and finally by Mahé [66] and by Amogu et al. [67] on the Sudanian tributaries of the Niger River.

In recent times, however, an increase in inundations has also been observed in Sudanian areas. In sharp spatial scale contrast, large areas from four countries (the southern part of Burkina Faso, the northern parts of Benin, Togo and Ghana) provided stream flows to tributaries of the Volta River in August and September 2007 during a flood event that was part of a very active monsoon. Paeth et al. [39] suggested that remote influences of anomalously high Atlantic SST (Sea Surface Temperature) and of a La Niña event in the Tropical Pacific played a role in this event. However, it is notable that the extreme rainfall event that occurred at Ouagadougou in 2009 was associated with very distinct large-scale and regional patterns [40]. These authors suggest that the occurrence of this 2009 event involved the combination of several favorable factors characterized by different scales (from the phase of the Madden-Julian Oscillation to the activity of African Easterly waves at that time).

\subsection{Impacts of Dams and Irrigation}

Damming significantly influenced the water balance of only the greater basins, such as the Volta [61], the Senegal [21,22] and the Niger. However, by comparing the dam-equipped basin of the Mono River (Benin) with the unequipped one of the Couffo River (in Togo), Amoussou et al. [27] observed (in relatively small basins) an annual excess of stream flow in 37\% of the Mono River after 1988 for a small increase in rainfall (+2\%), while they did not observe any modification in the "natural" Couffo River basin.

Otherwise, the Markala (since 1947) and Selingué (since 1980) dams management has affected the discharge of the Niger River. Up until 2008, the Markala dam diverted 7\% of the total discharge in dry years to supply the Office du Niger irrigated district (no effect observable in Figure 2, which begins in 1951). This district is nowadays $200,000 \mathrm{ha} \mathrm{big}$, and is mostly dedicated to rice cropping. The launch of the Selingué dam extended for 4 or 5 years the deficit of the Sankarani River, as did the Manantali dam after 1988 for the Senegal River. Both led to evaporation losses (1-2\% of the total discharge for the Sankarani River, 3-4\% for the Senegal River).

Since 2008, the extension of the irrigated district needed supplementary water volumes of 5 to $7 \%$. This has contributed to reducing the second peak by an amount ranging from 100 to $200 \mathrm{~m}^{3} \cdot \mathrm{s}^{-1}$. 
The management of Selingue dam aims to optimize the use of flood to allow irrigated rice cropping. It has not prevented the second flood from becoming more separated from the first one than previously after the Niger Inner Delta crossing. Ibrahim et al. (2017) [56] significantly improved the knowledge of the NID hydrological processes by applying remote sensing methods to more accurately estimate evaporation in the delta.

By contrast, neither in the upper Bani river basin located in Sudanian areas, nor in the Sahelian right bank tributaries of Niger River (Gorouol, Dargol and Sirba rivers), have the high number of dams (several hundred in the Bani, more than 700 small dams in the MNRB) built since the 1970s prevented an increase in runoff coefficient (Figure 5 for the MNRB).

\section{Upscaling of Hydrological Behaviors}

Hereafter, three kinds of geographical distribution of hydrological functioning are discussed.

\subsection{Evolution of Runoff Coefficient during the 1968-1990s Drought}

Figure 3 shows the evolution of runoff coefficient (RC) between the 1950-1967 and the 1968-1995 periods for all the documented basins in West Africa (as indicated in Table 1). The major facts to be highlighted in this map are the following:

- $\quad$ All the documented basins completely located in the Sahelian strip registered an increase in runoff coefficient during the dry 1968-1990s period. This finding is based on the studies dedicated respectively to the hydrological functioning of Sahelian $[2,9,19,26,41,44,45,47,67,68]$ and Sudano-Guinean $[25,27,28,57,59-63,69]$ basins, as well as comparisons between both series $[3,18,20,51,64,66]$.

- However, documented basins are far from covering the entire Sahelian strip. First, these basins are mostly located on exorheic areas, since endorheic ones, except the Lake Chad basin $[57,58]$ are generally composed of small catchments $[16,41,48-50,70]$ and are, therefore, not well documented. Otherwise, a great number of extended exorheic basins are either not or are no more extensively documented.

- $\quad$ Large basins (Senegal River at Bakel, Niger River at Niamey and Chari River at N'Djamena) are much more influenced by the decrease in runoff of their upper basins than by the probable increase in runoff of their Sahelian part. The upper basins generate 90 to $97 \%$ of their total discharge.

- The Bani River Basin is known to have experienced the largest decrease in discharges during the drought: $-70 \%$ between the 1951-1970 and 1971-1990 periods, and even an $82 \%$ decrease if considering only the 1980 s $[66,69,71]$.

- $\quad$ Finally, Figure 3 clearly highlights the contrast between:

- $\quad$ The pure Sahelian basins, where RC (and, for most of them, discharges) increased during the drought (1st hydrological Sahelian paradox); some of the right bank tributaries of the Niger River at Sahelian latitude and the Nakanbé are those where runoff coefficient increased more significantly; and

- $\quad$ Other basins, where, more intuitively, RC decreased. As shown by Amogu et al. [67], the decrease was more marked in Sudanian basins than in Guinean ones. As observed by Olivry [20] and Mahé et al. [19], in Sudanian regions, a decrease of 20-25\% in rainfall provoked a drop of 55 to $70 \%$ in discharges.

Otherwise, all the documented endorheic Sahelian basins also experienced a strong increase in runoff coefficient, and thus a rise in water body and lakes of seasonal or interannual duration in Mali, Mauritania and Eastern Niger [50], as well as in Western Niger [70]. 


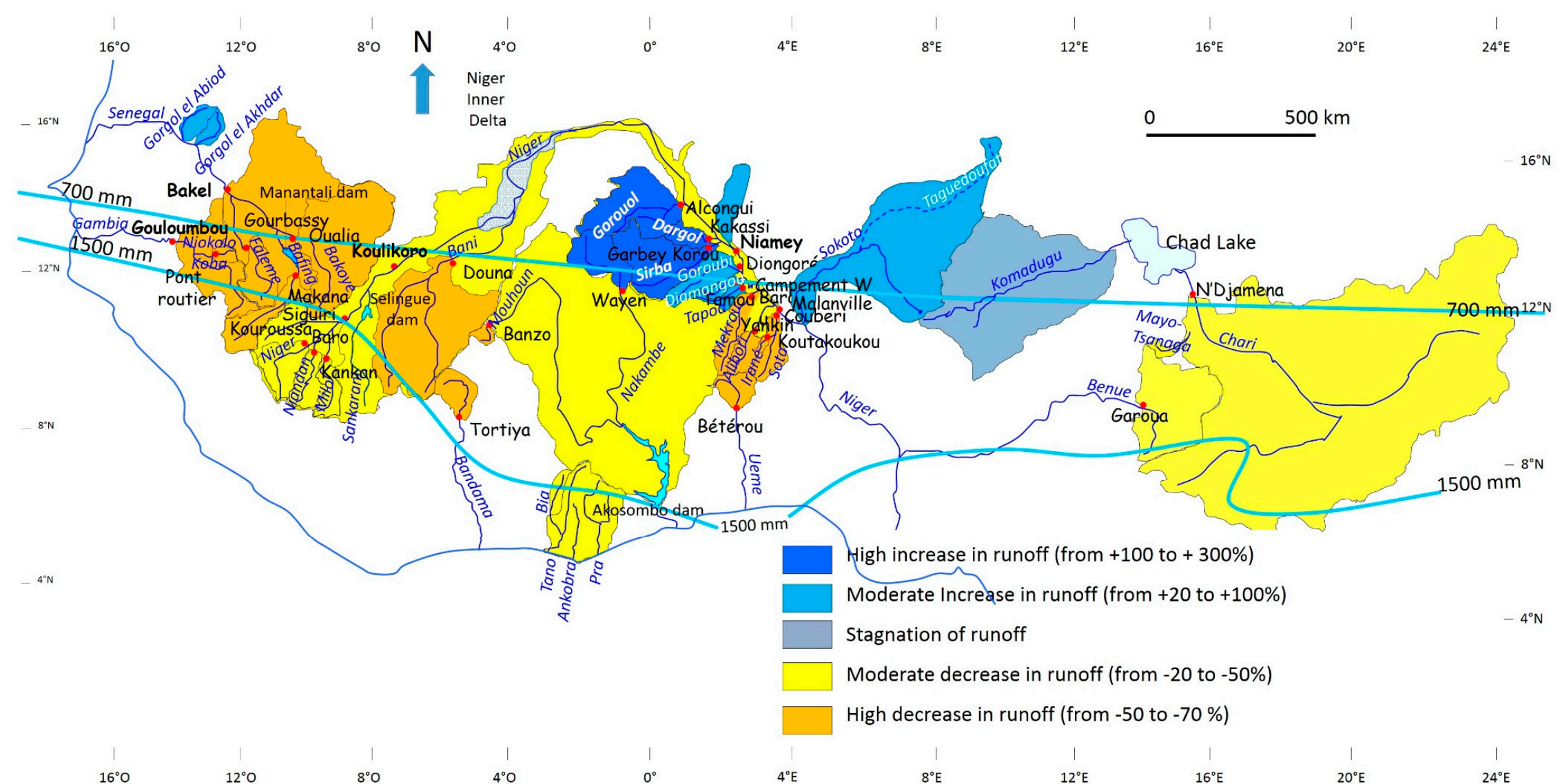

Figure 3. Evolution of river discharges between the 1951-1970 and 1971-2000 periods (updated and completed from [67]). Lines in light blue are the mean 750 and $1500 \mathrm{~mm}$ isohyets of the 1951-2000 period. 


\subsection{Comparison of Annual Runoff Coefficient Evolution from 1950 to 2015}

In this section, interannual RC evolution is analyzed for each basin. Then, in Figure 4, the basins are gathered, according to the pattern of their RC interannual evolution, in homogeneous classes of evolution. The comparison of interannual hydrographs allowed us to determine 5 main types of hydrological functioning; two of them including sub-types.

- The first one is composed of great basins, where Sudanian behavior predominates: they showed a strong decrease in runoff coefficient (RC) during the 1968-1995 drought (Figure 4a).

- The second type is the pure Sahelian type, characterized by an increase in RC during the drought, and an exacerbated increase observed with the rainfall recovery after the mid-1990s (Figure 4b).

- The third one is the "Sudano-Guinean type", where a partial RC recovery is observed after the rainfall recovery (Figure 4c), with two sub types 3-2 and 3-3 both characterized by a high part of missing data; type 3-2 gathers the basins with total recovery of $\mathrm{RC}$, probably linked to the "sahelization" of the basin and the increase in runoff on degraded or crusted topsoils (Figure 4d); type 3-3 is characterized by a very partial recovery of RC after the drought; it is composed of southern tributaries of the Niger River (Figure 4e).

- $\quad$ The fourth type is the pure Sudanian one, with no or very little recovery of the basins RC; this can be due to the high soil and landscape WHC, which imposes a very long refilling time of all the natural reservoirs (Figure 4f).

- The fifth and last type is the pure Guinean type, characterized by high RC in the smaller basins in recent decades; a partial recovery of RC is observed. This area is characterized by a long time (several years) elapsed before being impacted by the drought, due to the high volume of natural reservoirs taking years to be emptied. The subtype 5-1 is that of granitic areas with little reservoirs, strong slopes, and thin soils: the RC dropped 4-5 years after rainfall in 1975-1977 (Figure 4g); type 5-2 is that of the upper Niger basin, where low slopes and metamorphic and alluvial outcrops allow higher volumes of stored water; they lasted 7 to 9 years before showing a marked decrease in RC after the beginning of dry period, around 1979-1980 (Figure 4h).

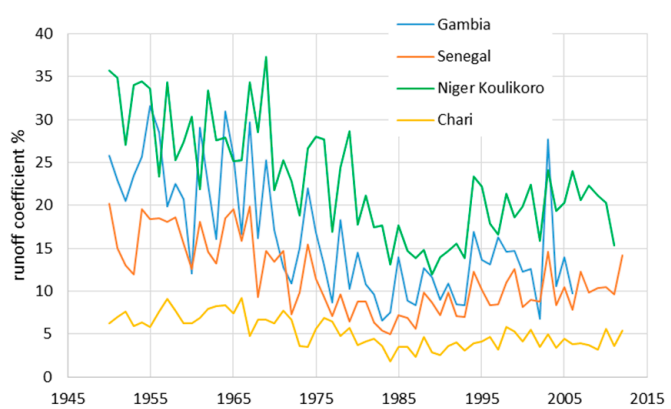

(a)

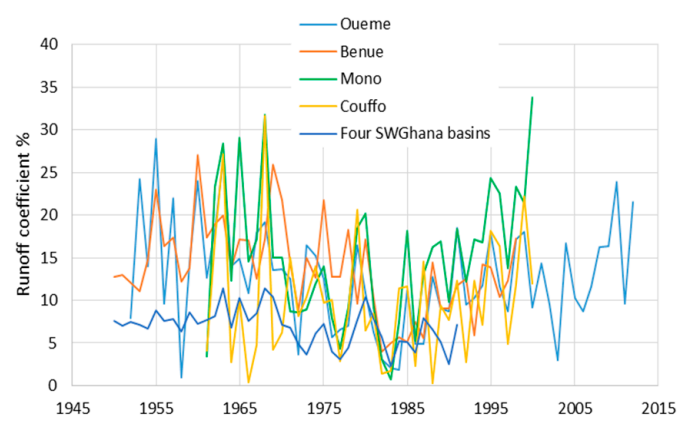

(c)

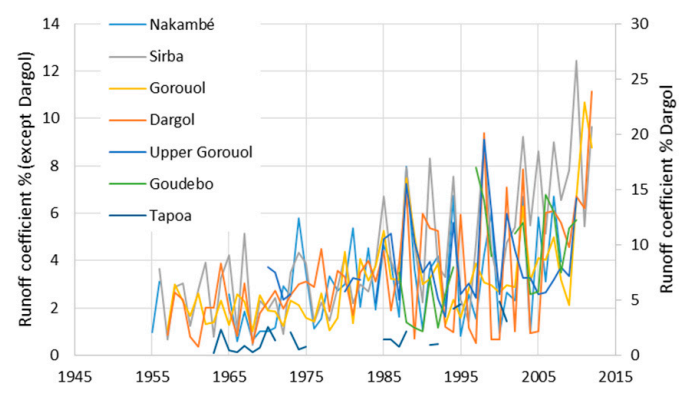

(b)

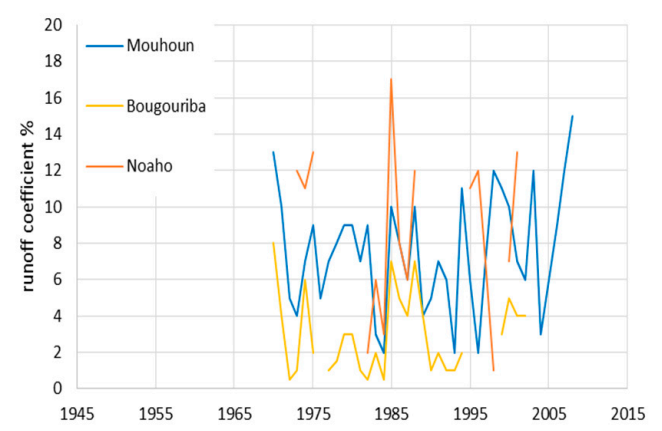

(d)

Figure 4. Cont. 


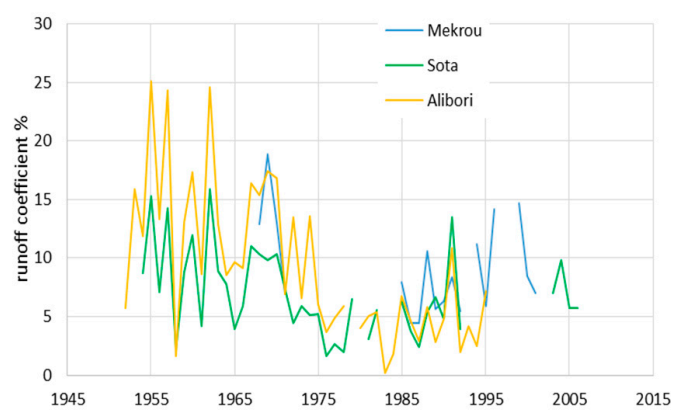

(e)

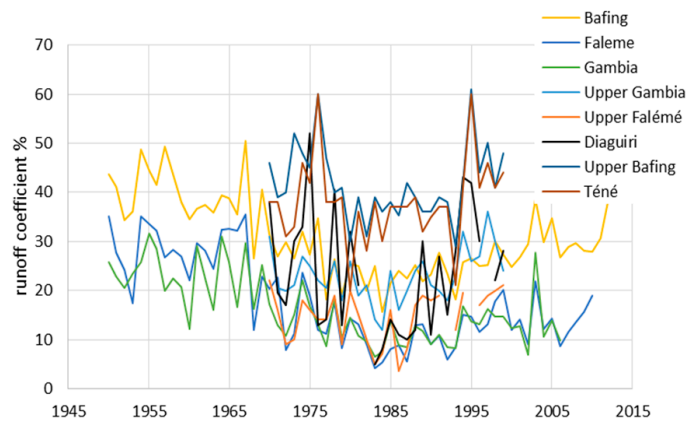

(g)

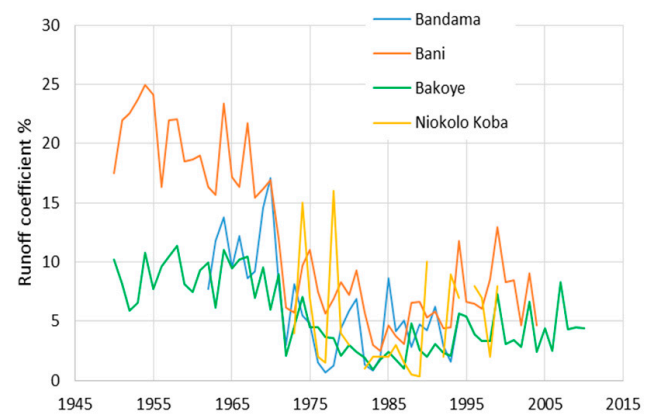

(f)

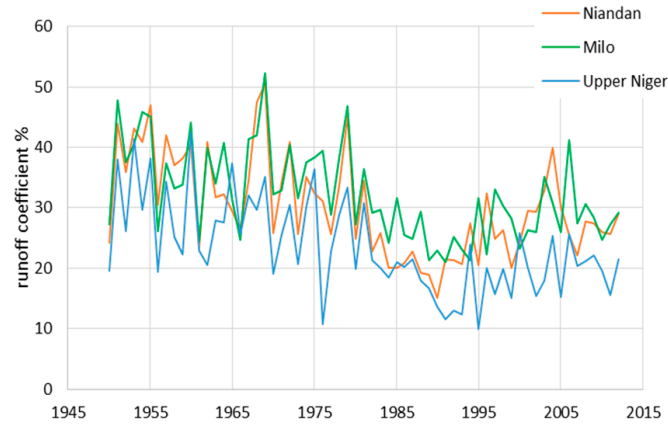

(h)

Figure 4. Interannual evolution of RC for the different types of hydrological behavior: (a) type 1: great basins: strong decrease during drought, long time in recovering $\mathrm{RC}$; (b) type 2: pure Sahelian functioning: increase during drought, exacerbated after the rainfall recovery; (c) type 3: Sudano-Guinean type with partial RC recovery; (d) type 3-2: Sudano-Guinean type with total RC recovery (but short series, with numerous missing data); (e) type 3-3: Sudano-Guinean type with little partial RC recovery (but short series, with numerous missing data, overall after the drought); (f) type 4: pure Sudanian type without or with very little RC recovery; (g) type 5-1: pure Guinean type with high values of RC, granitic basement sub-type (low WHC of the basins); the break of RC appears around 1975-1977; (h) type 5-2: pure Guinean type with high values of RC, "eastern" sub-type with high WHC of the basins; the break of RC appears around 1979-1980.

Figure 5 is a mapping of this regionalization by "hydrological" types. Its global pattern respects the zonal repartition between Sahelian, Sudanian and Guinean behaviors. It includes basins for which data are available in the literature. Eleven are described by Nka et al. [3], four by Opoku-Ankomah et al. [25], two by Amoussou et al. [27], one by Soro et al. [28], two by Amogu et al. [67], three by Badou et al. [59], one by Genthon (personal communication, 2017), and three by Mahé et al. [26] and Mahé and Paturel [9].

Figure 6 gathers the few hydrological series with available data for the period preceding the humid 1950-1967 period. It demonstrates that the main West African rivers did not recover their streamflow from the pre-humid period; this is probably the result of the long and deep emptying of natural reservoirs (ponds, humid areas, soils, rocks, altered rocks, water tables) during the long 1968-1993 drought.

The Bani River seems the most affected by this emptying and subsequent difficulty of recovering streamflow; however, its recorded data stopped in 2004. Inversely, the Niger River at Niamey is the one where the recovery is the clearest; while it is stronger than at Koulikoro, a purely Sudanian station, this is probably due to the great proportion of Sahelian areas in its basin. This is not the case for the Senegal River at Bakel, due to the weak proportion of exorheic zones in its Sahelian basin part. 


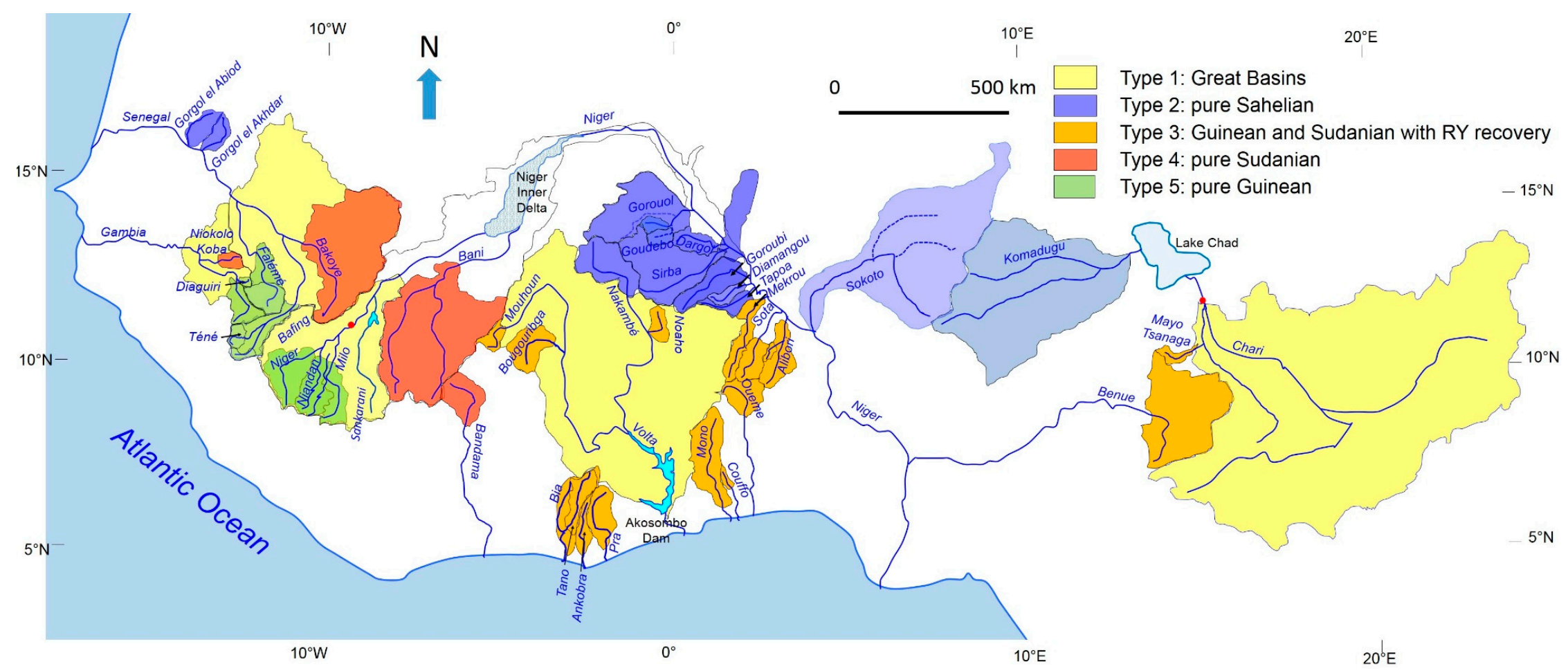

Figure 5. Classification of rivers basins according to the five described types (Volta River was added, despite the biases introduced by Akosombo dam, in Type 1, as the literature well describes its behavior); Sokoto is type 2, since an increase in RC is observed, but data are very sparse $[2,3,15,49,61,63,64,68,72]$; Komadugu has the same behavior as the Sahelian Basin (personal communication with Pierre Genthon, IRD). 


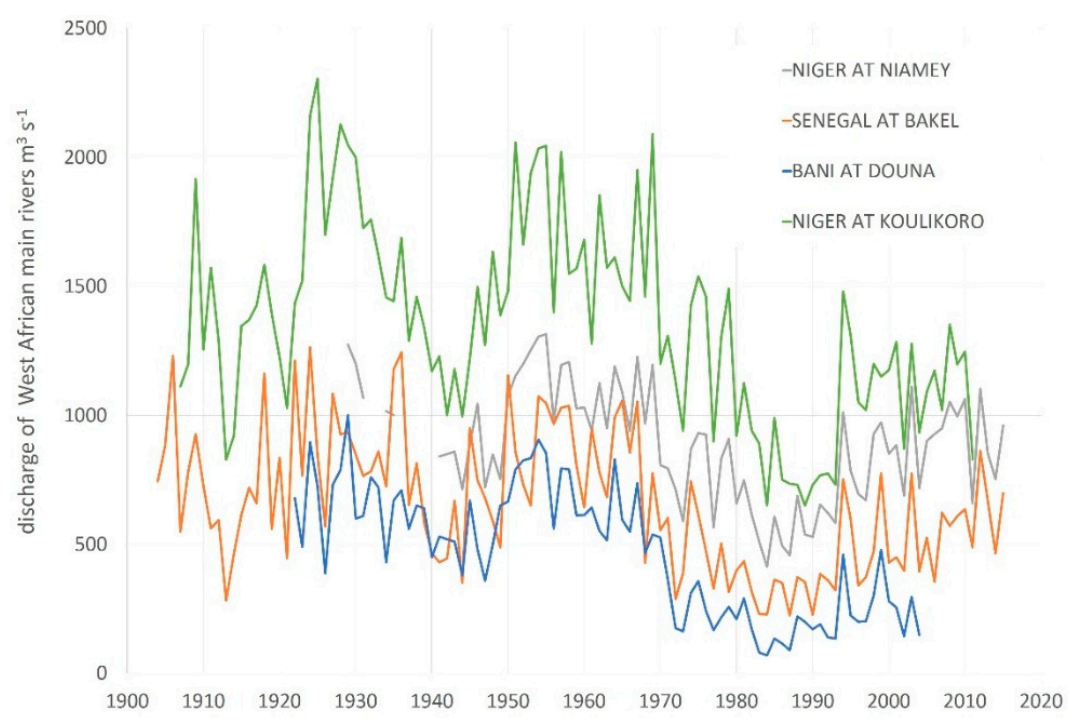

Figure 6. Discharge evolution of four basins: this comprises all the data available for rivers before the wet 1950-1967 period.

\subsection{A Principal Component Analysis (PCA) of Basin Hydrological Behavior}

The 18 longest series of annual data (more than 50 years; 63 for 12 of these 18 series) were used for a PCA analysis in order to obtain statistical upscaling. The two main components ( $65 \%$ of explained variance) allowed us to segregate three main groups of basins (Figure 7): the first is composed of the four pure Sahelian basins where the "Sahelian paradox" was observed. The second class is composed of nine Sudanian basins, whose discharge was strongly affected by the rainfall deficit. The third group is the one gathering the five Guinean basins and sub-basins of the upper Niger River; their discharge decrease was lower during the drought, but their stream flow recovery seems delayed, probably due to the long time necessary to fill the natural reservoirs (ponds, wetlands, soil, sub soil, water tables), which allowed it to maintain, during the twelve first years of the rainfall deficit period, the discharge and RC at their previous levels.

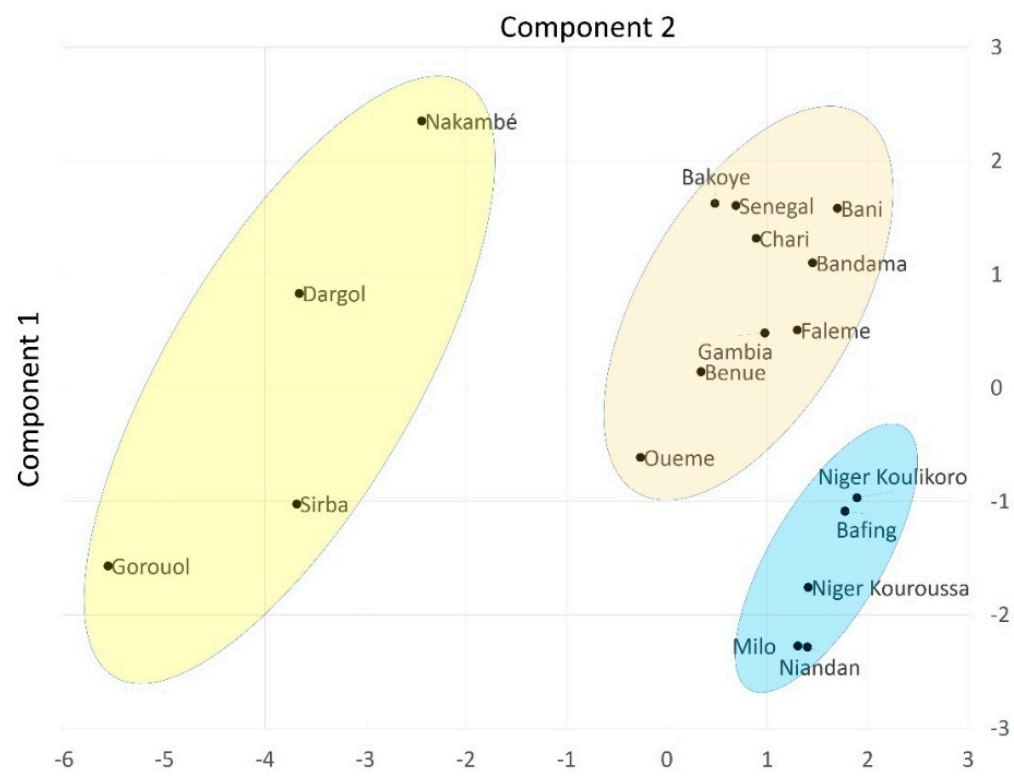

Figure 7. The classification of the main components of the PCA study; the two components concerned explain $65 \%$ of the variance. 
The two main components identified by this PCA both explain $65 \%$ of the variance. The first one $(40 \%)$ is determined by: \% RC evolution during drought (number 11 in Table 2, Section 2.2.3, above), $\%$ RC evolution after drought (12), \% discharge evolution after the rupture (7) and \% rainfall decrease during drought (3). The second component ( $25 \%$ of the explained variance) is determined by basin area (1), \% rainfall recovery after drought (4), mean annual RC before drought (10) and finally by time elapsed between rainfall break and RC break (9).

\section{Land Use/Land Cover Changes and Their Hydrological Consequences}

West Africa includes some clear Boserupian [72-75] socio-economic models: densely populated areas succeeded over many centuries in maintaining soil fertility and high crop yields. The south of the ex-groundnut belt of Senegal, the Dogon country in Mali, the Mossi plateau in Burkina Faso, the Maradi area in Niger, and the central Fouta Djallon in Guinea have for a long time featured dense populations and non-degraded soils and landscapes. However, in extended areas, the extension of crops and the long drought 1968-1995 created large areas of bare soils exposed to crusting, erosion and runoff $[14,18,20,41,67,68,70,76-78]$.

Clearly, part of land cover change is due to climate evolution [41,67,78]; tiger bush, gallery forests and other kinds of vegetation strongly suffered during the long rainfall deficit period. Hereafter, we merge the two kinds of land use and land cover evolutions, both processes similarly modifying surface hydrological properties. More particularly, they caused a significant (sometimes paradoxical) reduction in the soil WHC, which increased runoff coefficients and discharges.

The question of whether climate or LULCC are the main explanation for the increase in runoff coefficients and discharges has been frequently addressed in recent years. It has for a long time been assumed that the 1st Sahelian paradox is mostly due to LULCC, initially via the bare soil exposure induced by land cropping and by vegetation dying, and then by soil crusting in some years due to soil properties, the above-cited removal of vegetation on thin soils, and finally the formation of bioderm (algal crust) in 5-6 years old fallows $[6,18,19,51,77]$. However, recent studies have reached more mitigated conclusions. Among others, Aich et al. [38] argued that LULCC and climatic changes could contribute to different degrees in the different basins.

\subsection{Some Concepts in Land Use/Land Cover Change Studies}

Land Use/Land Cover Changes and the associated changes in surface hydrology have been identified as the main explaining factor of the 1st Sahelian paradox. Some authors $[2,6,7]$ showed that neither the mean yearly rainfall amount nor the extreme rainfall events in the most recent periods (2001-2010 and 2011-2015) exceeded those of the 1950-1967 period, while Sahelian rivers' discharges are now 3 or 4 times higher than during the pre-drought period. Considerable effort has been dedicated to determining the impact of LULCC since the beginning of the great drought (1968-1990s). Since initial research by Prince et al. (1998) [79] demonstrating that RUE (Rain Use Efficiency = Net Primary Productivity/Rainfall) slightly increased at the subcontinent scale between 1982 and 1990, many works have largely confirmed this trend in the subsequent years ([10-12,14,33,34,80], among others). The use of RUE is not simple, though, and that value can increase with rainfall; this has given rise to different interpretations (Prince et al. [11]; Hein and De Ridder [81]).

\subsection{Evaluation of Global Vegetation Evolution through Remote Sensing Studies}

Figure 8 shows that there are areas where NDVI is decreasing in the Sahelian strip. As shown in most of the literature, there is a general re-greening in the whole Sahel except in Niger and central Sudan. The western part of Niger is also commonly observed as an area with decreasing NDVI values, as observed by Hountondji et al. [82] and Dardel et al. [83] (Figure 8). Clearly, extended areas of the Iullemeden basin east of Niamey (left bank of the Niger River) are experiencing an ongoing desertification of the ferricrete plateaus (or at least a decrease in vegetation cover), the sandy soils basin and valleys showing a slight increase in woody plants [14] are far from compensating the strong 
decrease in vegetation cover observed from 1965 to 2010 in both areas, as well as in the slopes of the Niger River valley and lower basins of right bank tributaries [72]. Conversely, general regreening can also be observed in the middle and upper basins of the main Sahelian right bank tributaries of the Niger River. This was also corroborated by San Emeterio [14]. The general trend in the studies published since 2005 (Figure 8) is that the re-greening does not concern the northern-most part of the Sahel. Due to the low significance of the satellite detection capability in areas of very sparse vegetation, this has only been partially verified. Hiernaux et al. [84,85] and Mahé et al. [19] observed that most of the deforestation (or desertification, or decrease in vegetation cover) was located in southern Sahel, and was due to the increase in crop areas, while grazing areas (rainfed cropping is very scarce northward from $300 \mathrm{~mm}$ of yearly rainfall amount) were re-greening due to recovering rainfall amounts $[83,86]$.

Field observations show that re-greening does not inevitably lead to an increase in WHC. The first drought peak (1972-1973) provoked the death of a large fraction of low vegetation; the second drought peak (1982-1984) caused great mortality in trees and bushes. Both events strongly altered the WHC, causing soil crusting and roughness decreases $[18,68,77,87,88]$, as well as decreases in root depth. All these changes slow down infiltration and favor runoff and erosion.

Brandt et al. [89] confirmed an overall positive trend of woody cover dynamics across the entire Sahel in recent decades. This demonstrates the resilience of Sahelian ecosystems, although this trend is generally observed in places with low human pressure. Brandt et al. [15] further identified the pastoral area of Senegal as the area with the largest increase in woody cover within the Sahel. The increase is more pronounced in protected areas ("forêts classées") than in reforestation areas such as the Great Green Wall. As previously observed by Hiernaux et al. [85], Gardelle et al. [48], Dardel et al. [13] in Eastern Mali, Brandt et al. [15] showed that in Senegal too, lower vegetation recovery occurred over shallow soils (here in ferrugineous plateaus of the Ferlo), where they observed "mass dying of trees on lateritic soils during droughts". Bamba et al. [90] observed that the increasing trend in vegetation greenness is extending from the South to North. In addition, Brandt et al. (2018) [91] recently showed that cropland supports higher tree cover than non-cultivated land in central and northern Sahel, whereas the reverse situation prevails in southern Sahel.

As shown previously, most of the upper and middle basins of MNRB are included in the re-greening area between the 1980s and the 2000s (Figure 8), at least those of the three main right bank tributaries (Gorouol, Dargol and Sirba rivers). These constitute the area where the increase in discharge and runoff coefficient $(\mathrm{RC})$ is the most pronounced. In these three basins, runoff coefficients are at least 4 times larger (see Figure $4 \mathrm{~b}$ ), and discharges at least 3 times larger, than the ones observed during the 1950-1970 wet period. This is why this area is the most studied (focused on) within the Sahel $[2,3,6,7,9,19,46,51,54,67-70,76,78]$. Contrary to the sole Niamey area, MNRB is therefore representative of the whole Sahel in terms of land cover evolution [10,12-14,33,34]. The 2nd Sahelian paradox completely applies in this area.

A detailed study carried out on the Agoufou watershed in a pastoral area in northern Mali showed important changes in vegetation and soil properties between 1956 and 2011 at the watershed level [49], despite the general re-greening observed in this region (see location in Figure 1b). The observed changes include partial crusting of isolated dunes, increase in drainage network density, degradation of tiger bush [92] and of the vegetation growing on shallow soils, and shallow sandy sheets being eroded and giving place to impervious soils. This evolution of vegetation and soil properties contributed to increase surface runoff [49].

\subsection{Highlighting the Correlation between Land Use/Land Cover and Runoff Yield}

The first Sahelian paradox has commonly been attributed to LULCC. In cultivated areas of the Sahel, the extension of soil "erosion-crusting" (see description below) [72,76] has led to directly exposing topsoil to successive intense rainfall events and severe drying episodes. This "erosion-crusting" mainly concerns newly cropped typical Sahelian sandy soils and is most often assumed to be a consequence of land clearing and extension of cropping $[6,93,94]$ (land use change). In pastoral areas, during the drought, 
the removal of the thin lithosol by wind or water erosion, occurring because of the vegetation dying, led rocks to outcrop $[16,49,72,95]$ (land cover change).

Nka et al. [3] performed one of the rare studies based on small basins across all of West Africa (and including some tributaries of MNRB). They highlighted the opposite trends in flood magnitude and flood frequency depending on the climatic zones: the Sahelian catchments studied showed increasing trends in both flood magnitude and frequency, due to the increase in annual runoff coefficients, and the increasing amount of heavy rainfall events. Runoff is triggered by the presence of bare, crusted soils, in all types of sloping areas, and sheet floods become concentrated floods and dig gullies with sharp, quasi-vertical edges, which can cross the whole slope through the main wadi. In flat, non-cropped areas (lateritic plateaus and other ledges in the topography), runoff commonly starts on deflation patches $[6,87,96]$. These patches become coalescent, forming new channels, and then gullies.

In northern areas of the Sahel, beyond the limit of possible dry farming, space is mostly dedicated to livestock. Thus, the observed increase in runoff and pond water surface in this area $[49,51]$ cannot be due to an extension of croplands, but probably to another kind of land cover change. This also commonly begins by the formation of deflation patches appearing due to the vegetation dying during the extremely dry 1972-1973 sequence [97]. This led to sheet runoff becoming concentrated runoff, and to the wiping out of the Sahelian tiger bush system [92]. Gal et al. [16] and Gal [49] suggested that these changes in soil properties and vegetation cover (grassland and bush thickets degradation) explained this increase in runoff and pond water surface. More precisely, the thin lithosol and regosol soil types, including the rock-ferricrete outcrops (they constitute $20-25 \%$ of the total soil extension; $[50,84,85]$ ) were wiped out during the long drought period (1968-1995). This removal was due to the vegetation degradation, which was strongly affected by drought, especially over shallow soils with low WHC. These shallow soils are currently being eroded and replaced by impervious soils, characterized by high runoff coefficients; this is the main explanation of the "second Sahelian paradox" (increasing runoff in spite of re-greening) observed by Dardel et al. [13]. These authors showed that this functioning observed in the Gourma region (Mali) can be explained by the heavy contribution of small fractions of the landscape showing signs of degradation (and yielding high streamflows), while the sandy soils that dominate the landscape were resilient, with a strong regreening trend. A significant part of the runoff comes from upstream areas: the ferricrete plateaus, and lithosols-regosols areas of rocky parts of the basins. The strong reduction of the previous vegetation cover of these areas makes them yield increasing streamflows, which have to cross the whole hillslope, creating new gullies through grazing and crop areas $[78,88,98]$. This could lead to an increase in the drained area of a basin in the Malian Gourma [16]. This process should also locally contribute to the increase in runoff in the croplands areas, as described by Souley Yero et al. [76] and Descroix [72] for two basins near Niamey (Niger), the first one located on granitic basement, the second one on sedimentary terrain. This is not necessarily at odds with the global re-greening, as also observed in the SW of Niger [94]. However, Roudier et al. [42], conversely, considered that land use dynamics do not offset the effects of climate change on runoff in West Africa. At a broader scale, Mahé et al. [26] recently proposed a synthesis of the hydrological behaviors observed throughout the whole Atlantic side of West Africa, ranging from the Maghreb to the Congo River mouths.

Finally, the study of the major yearly flood of the Middle Niger River in 2010 highlighted the relationship between soil crusting and increasing flooding and inundation hazards in West Africa [1,2].

\subsection{A Common Explanation: The Reduction of both Hydraulic Conductivity and Roughness}

In pastoral northern Sahelian areas, the previous erosion stage described produced rock outcrops and explained the observed increase in gullying and in runoff coefficients. Gal et al. [16] showed that the vegetation was quite efficient at slowing down water flow, and therefore that vegetation degradation results in a reduction of soil surface roughness (expressed by the Manning coefficient). A low Manning coefficient is one of the main features of ERO crust (ERO = "erosion crust" [88]). 
Soil ERO (overall) and ST (secondarily) (ST = structural crust [88]) crusting have been observed for decades in cropped areas in the Sahel, and have been interpreted to be a consequence of land clearing, reduction of fallow and locally non-adapted rural practices; the ERO crust is clearly due to the previous soil degradation caused by water and wind erosion on bare surfaces. The "ERO" crust was described by Casenave and Valentin [88], as recalled by Descroix et al. [2]: it is constituted of a thin, smooth, clay-rich surface layer overlying a 20-50 cm thick erosion-type sand layer (ERO), crusted by splash, runoff and desiccation. This trend inspired the edaphic classification of semi-arid climate soils by their "surface features", rather than by soil types [94]. The pre-determined classes of "surface features" are commonly the same, whatever the soil type, indicating their "azonality" and the major interest in classifying soils according to their WHC.

Malam Abdou et al. [68] observed that runoff was higher on crystalline basement due to both the extension of outcropping and the few altered granite and "gravel-crust" features, on the one hand, and little infiltration in the gullies, on the other hand. This was consistent with previous findings on basement by Descloitres et al. [99], who observed a low infiltration under the gullies. Finally, the research by Malam Abdou et al. [87] could constitute a first attempt of regionalization of the soil WHC in the Sahel, updating that by Descroix et al. [51], based on the matching of exorheic/basement areas, as opposed to endorheic/sedimentary ones. However, both are characterized by lateritic plateaus (ferricrete hard pan) dominating long gentle hill slopes, able to generate high runoff coefficients. Malam Abdou et al. [87] assessed the evolution of soil surface on a small watershed in Western Niger.

These areas are characterized by a mosaic of crops and fallows. On both land covers, hydraulic conductivity is the lowest in the first three centimeters. However, in crop areas, soil properties evolve under weeding impact; this causes a superficial redistribution of soil structure, and rainfall blocks macropores. Weeding increases conductivity by up to $120 \mathrm{~mm} \cdot \mathrm{h}^{-1}$, but after some rainfall events, it decreases strongly.

After $50 \mathrm{~mm}$, Ks is below $25 \mathrm{~mm} \cdot \mathrm{h}^{-1}$, and after 200 or $250 \mathrm{~mm}$ of rainfall, weeded soils have the same infiltration rate (conductivity) as the "ERO" crust $\left(10 \mathrm{~mm} \cdot \mathrm{h}^{-1}\right)$, due to progressive soil crusting of crop areas [87]. Based on a great number of measurements realized from 2004 to 2011 on very different sites in western Niger, Descroix et al. [2] showed that Ks decreased from $172 \mathrm{~mm} \cdot \mathrm{h}^{-1}( \pm 79$; 20 measurements) in a millet well weeded to $10 \mathrm{~mm} \cdot \mathrm{h}^{-1}( \pm 5 ; 20$ measurements) in a millet field where soil is now crusted (Table 3). At the micro-catchment scale, Amogu et al. [78] observed that an increase in the extension of crusted soils led to a similar increase in runoff coefficient.

Table 3. Comparison of the hydrodynamic properties of non-crusted and crusted soils [2].

\begin{tabular}{ccc}
\hline Soil Surface Feature & Runoff Coefficient (\%) & $\begin{array}{c}\text { Saturated Hydraulic } \\
\text { Conductivity (mm·h }\end{array}$ \\
\hline Millet on common sandy soil just after weeding & $4.0 \pm 1.4$ & $172 \pm 79(20)^{*}$ \\
Fallow on common sandy soil & $10 \pm 4$ & $79 \pm 41(20)$ \\
Old fallow with bioderm & $25 \pm 7$ & $18 \pm 12(30)$ \\
Millet and fallow erosion (ERO) crusted soils & $60 \pm 8$ & $10 \pm 5(30)$ \\
\hline
\end{tabular}

${ }^{*}$ Number of repetitions.

Therefore, in northern pastoral areas as well as in southern cropped areas, both vegetation degradation and soil crusting led to an increase in surface runoff. 


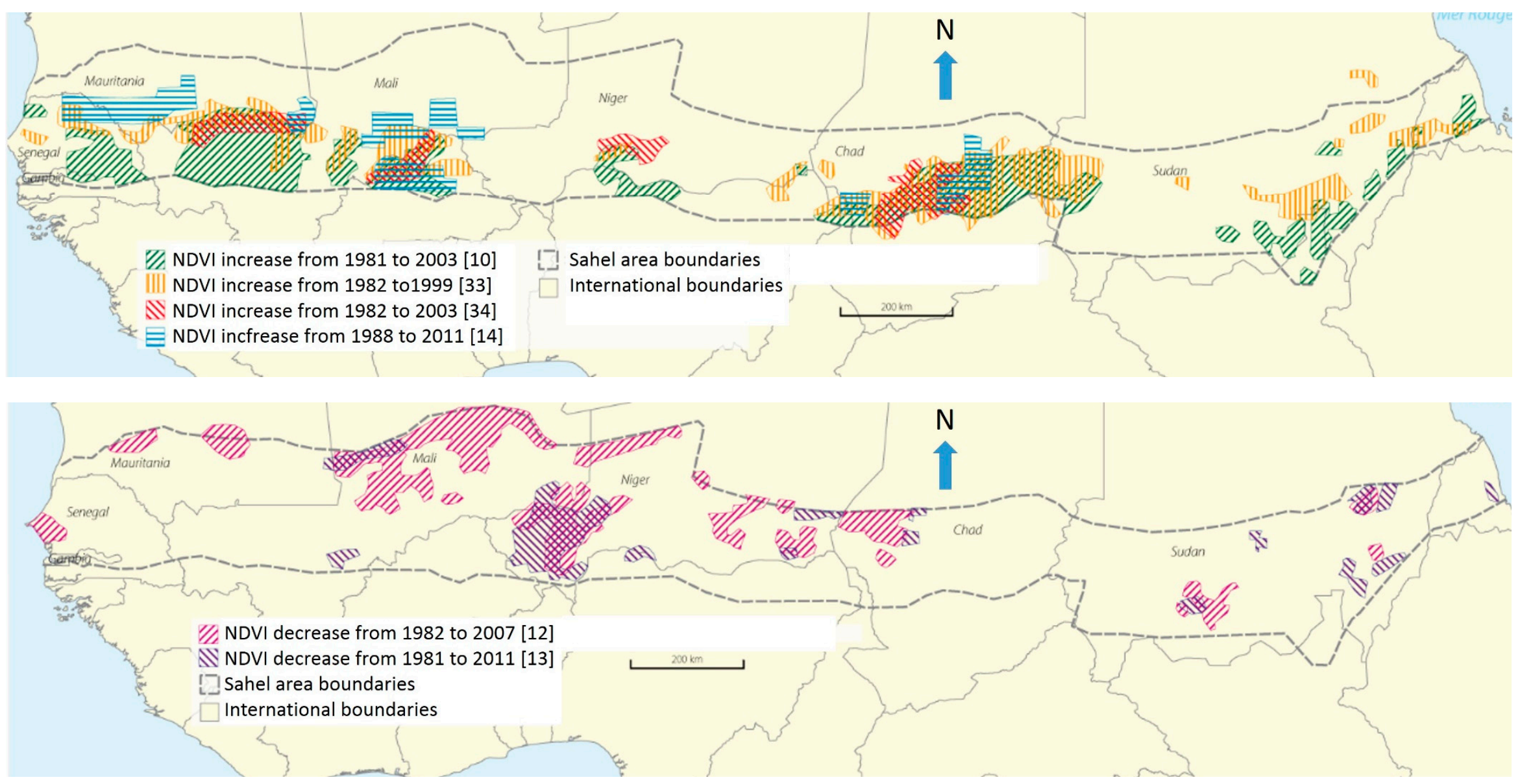

Figure 8. Areas of increasing (up) and decreasing (down) NDVI between the 1980s and the 2000s, according to published research $[10,12-14,33,34,82,83,100]$. 
Malam Abdou et al. [87] explained that pearl millet fields could function for $80 \%$ of the duration of the rainy season, with Ks values much lower than rainfall intensity. At the Banizoumbou station, $65 \mathrm{~km}$ eastward from Niamey, $75 \%$ of the yearly rainfall has an intensity higher than $30 \mathrm{~mm} \cdot \mathrm{h}^{-1}$, and $43 \%$ has an intensity higher than $60 \mathrm{~mm} \cdot \mathrm{h}^{-1}$. Thus, clearly, weeding significantly improves Ks on sandy soils, but it only has an effect during one or two main rainy events, after which crusted soils are associated with extended areas where only one weeding is carried out. Such a reinforcement of soil crusting in sandy soils was observed in the southern part of the "groundnut belt" of Senegal after harrowing and then $160 \mathrm{~mm}$ of cumulated rainfall [77]. Otherwise "old" fallows (4 or 5 years after the last harvesting) have been observed to be prone to colonization by bioderm (algal crust), which is well known to have low Ks, due to the hydrophobic characteristic of organic matter.

Moussa Issaka et al. [101] noticed that in the lower Yobe-Komadugu river valley (a tributary of Lake Chad; the river's basin covers northeastern Nigeria and southeastern Niger), a degradation of various geomorphological units was observed, with significant environmental changes between 1957 and 2007; overall, the alluvial plain (Kadzell) is threatened by soil crusting and Yobe River bank retreat. The encrusted soils area was shown to have increased from 76 ha in 1975 to 230 ha in 2007 in their study area [101]. Soil crusting seems to be generalized in the Sahel, due to various processes.

\subsection{Some Exacerbating Processes}

\subsubsection{Urbanization}

The severe inundations that affected the Sudanian northern Ghana and Togo in August and September 2007 were among the first ones noticed in extended rural areas; a similar event was reported on 31 August 2013 in the Sine Saloum region of Senegal, where $300 \mathrm{~mm}$ of rainfall was recorded in 2 days. In 2014, the rural area of Dantiandou, in western Niger, suffered severe flooding that caused considerable damage and killed several people. However, society and the media in general focus on urban flooding.

The flood that destroyed the "Gounti Yena" market at Niamey (Niger) on 28 April 2004 is memorable for two reasons. The first reason is that it occurred almost two months before the average monsoon onset at the Niamey station. The second reason is that it was the beginning of a series of floods, which are becoming larger and more frequent. It was caused by a very small left bank tributary of the Niger River, in the city. Therefore, after the flood of Niamey, two events occurred on 1 September 2009. By the morning, the city of Ouagadougou was affected by the highest rainfall event ever observed at this place- $270 \mathrm{~mm}$ in a few hours-which caused the inundation of a great part of the city and very severe damage to the built areas and population [37]. By the afternoon, Agades, located several hundred $\mathrm{km}$ away in northern Niger, was flooded by the overflow of the Teloua kori (wadi in Hausa), which also caused significant damages in this city. In 2010, 2012, 2013, 2016 and 2017, Niamey (Niger) was inundated by the overflow of the Niger River, which reached, among these years, three times its highest ever observed water level.

Similar to Ouagadougou, Dakar has no river. It was nevertheless seriously affected by a strong rainfall event by 26 August 2012, when $156 \mathrm{~mm}$ of rain fell in less than $2 \mathrm{~h}$; this was the second-largest daily rainfall amount observed in Dakar since 1896, but the highest rainfall intensity event ever registered [72]. Large areas of the northern part of the city were inundated. One year later, on 30 August 2013, Bamako (Mali) in turn was flooded by stream flows generated over partially urbanized hills dominating the northern part of the city, causing severe damages (53 people died).

Urbanization clearly has a double impact:

- On the runoff, by decreasing infiltration: urbanization is known to lead to soil compaction and sharp reduction in water infiltration. It is both a cause of flooding due to high runoff coefficients and a cause of aggravated consequences of flooding, due to inundation and the damage to the built environment. Additionally, gutters are commonly clogged when no maintenance is routinely implemented, as it was observed in Bamako in August 2013; 
- On cities and peoples' vulnerability: flooding caused severe damage in unplanned urbanized areas, which have developed rapidly in sub-Saharan cities in recent decades, and are widespread in flooding zones due to both the strong migration pressure and limited control over this urbanization.

\subsubsection{Silting Up}

Decrease in soil WHC doesn't only lead to increase runoff coefficients and discharges. Stream flows carry increasing volumes of sediments from soils, due to both the land clearing and its consequent soil crusting. A high runoff coefficient significantly increases the sediment load of stream flows. Intense Sahelian rain events destroy soil aggregates, and runoff quickly causes the formation of gullies, which leads to high sediment transport [102-104]. This is the origin of sediments accumulated in alluvial fans in main rivers, mostly in the Niger River bed. These alluvial fans can provoke a severe reduction of the hydraulic section of rivers, as occurred in 1998 just upstream from the city of Niamey (Niger), when floods coming from the Kourtéré basin built a big fan, which invaded more than $20 \%$ of that section of the Niger River [104]. A great number of alluvial fans have been invading the Niger riverbed, as well as those of some tributaries. This reduction of river cross-section makes water overflow more frequently; it is one of the basic causes of the increase in flooding frequency in Niamey [104].

\subsubsection{Endorheism Rupture}

Dynamic runoff and erosion explain the rising frequency of endorheism rupture events over the last decades. Both the filling of ponds by the runoff and their silting up by sediments promote their overflowing, leading to the creation, in tens of minutes, of new channels driving stream water and solid discharge through to the main rivers, chiefly the Niger River. The multiplication of such events before, but mostly during, the dry 1968-1990s period constitute the origin of an increase in the Middle Niger Basin area, and therefore its area in Sahelian geo-climate. In the sole Niamey area, the Niger River basin gained $1700 \mathrm{~km}^{2}$ in the last 50 years [104]. In a very flat topography, some wadis could capture another one, as it occurs commonly at the small scale (some hectares) in the cropped area near Niamey, and at the regional scale (some $10 \mathrm{~km}^{2}$ in the Agoufou catchment) [49].

\section{An Intensification of Rainfall}

Due to the small number of rainfall stations, we will mainly analyze the rainfall evolution for the 1950-2015 period. After summarizing the main trends described in recent research (Section 6.1), three main ways are used to highlight the current rainfall intensification:

- Determining the interannual evolution of rainfall amount and rainfall indexes, including the evolution of both the number of rainy days and the daily rainfall amount (Section 6.2);

- Analyzing the interdecadal evolution of number of extreme events (here, daily rainfall amounts exceeding 60, 80 and $100 \mathrm{~mm}$ ) (Section 6.3);

- $\quad$ Studying the annual evolution of monsoon onset and the effectiveness of the monsoon according to agronomical criteria (Section 6.4).

\subsection{Main Trends Described in Recent Works}

This began with a strong rainfall excess between 1950 and 1967. The period from 1968 to the 1990s was a long deficit period all over West Africa. It lasted until 1993 in eastern and central Sahel, and until 1998 in the western part of this region. From the end of the 20th century, rainfall amount increased and almost reached its 1900-2015 average.

Two trends were observed:

- Locally, a rise in inter-annual variability compared with that observed before the dry period;

- All over the Sudano-Sahelian strip, since the minimum of the 1980s, an increase in extreme rainfall events, more pronounced that the increase in annual rainfall. 
Nicholson [105] conducted a very complete review of rainfall studies over West Africa, and particularly the Sahel. This author synthesized recent trends, demonstrating that rainfall in the Sahel has shown some degree of recovery since the 1970s and 1980s drought. She highlighted that rainfall regime changed, showing less spatial coherence and less temporal persistence. Furthermore, the peak month appears to have shifted from August to July. In addition, the statistical analysis of rainfall over Central Sahel by Panthou et al. [4] shows that the contribution of extreme events to the cumulative annual rainfall is higher now (since 2000) than during the wet period [1950-1969]. Taylor et al. [5] identified, using satellite infrared temperature (IRT) data, a robust and strong positive trend in the frequency of intense Sahelian mesoscale convective systems (MCS) since 1982 (in which MCS-mean IRT was used as a measure of intensity). Similar conclusions emerge from Sanogo et al. [106] and Zhang et al. [107].

A critical and controversial point is the question of the feedback between land and convective processes. A few studies have used remote sensing data to track the MCS and explore their potential couplings with surface processes. Taylor et al. $[108,109]$ showed that soil-moisture heterogeneity on scales of tens of kilometers has a pronounced impact on rainfall at the larger scale in the Sahel. This occurs because the MCS expands for hundreds of kilometers. In addition, they showed that "the new soil-wetness patterns produced by an MCS in turn increase the probability of another MCS in the following day or two". Pellarin [110] reached a similar conclusion and observed that the initiation, but also the path and behavior of MCS appear to be influenced by the soil moisture patterns during daytime, their path evolving preferentially on the edge of wet areas. Sy et al. (2017) [111] showed that, although climate responses to land use changes seem to be relatively small, some atmospheric processes are influenced by LULCC.

Aich et al. [93] and Cassé et al. [54] showed that during the dry period (1st Sahelian paradox), LULCC was the main explanatory factor of the increasing stream flows, while, since the annual rainfall recovery period (since the end of the 20th century), rainfall intensification has also contributed to this trend, the respective roles of both being difficult to determine. In addition, two series of facts could complete this statement:

- Rainfall decadal variability induces land cover changes, such as ligneous vegetation dying, due to severe drought; this vegetation cover reduction could, in time, explain the increasing runoff and discharges;

- Some studies $([2,78,87,95,104]$ among others) have demonstrated that the re-greening does not prevent the increase in runoff and in basin discharge, due to the severe degradation of small parts of these basins, generally located near the "kori". The intensification of rainfall began in the middle of the 1980s, but it reached its maximum in the middle of the 2001-2010 decade [4,7]. At that date, at least $90 \%$ of the increase in stream flows had already been realized. The rainfall evolution in West Africa contributes to the increasing trend of runoff and rivers discharges. Below, several indicators are used to assess this contribution. More precisely, we analyze the annual rainfall amount, rainfall index, rainfall intensity and monsoon seasonal pattern. In this section, we will analyze the spatio-temporal evolution of daily rainfall for two areas: Senegambia and the MNRB (see location in Figure 9), and for the 1951-2015 period.

\subsection{Annual Rainfall Amount and Indexes}

The annual rainfall amount achieved its mean (1900-2015) level in almost all of West Africa [80, 112] in 1999 [7] or during the 2001-2010 decade [4], although this is regarded as controversial by other authors, as highlighted Nicholson [105]. In fact, the controversy mostly arose because the annual rainfall recovery has been relatively recent, and so the use of different data sets (including different sites and time periods) has led to some differences. However, one figure (in Nicholson [105]) indicates a rainfall deficit from 2000 to 2003; yet Figure 10 rather shows that the trend has been around the mean since 1999, including in Senegambia, the most western part of the Sahel region. As shown below, some differences remain between the considered data sets (rain gauges, stations and periods). 
Using daily rain gauge data across Central Sahel, Panthou et al. [4] showed that since the mid 2000 decade, the Sahelian rainfall regime has been characterized by a lasting deficit in the number of rainy days. These authors highlighted that, at the same time, extreme rainfall occurrence is rising. In the MNRB, as in Senegambia, the annual rainfall index reached its 1900-2015 average value at the very end of the 20th century [7].

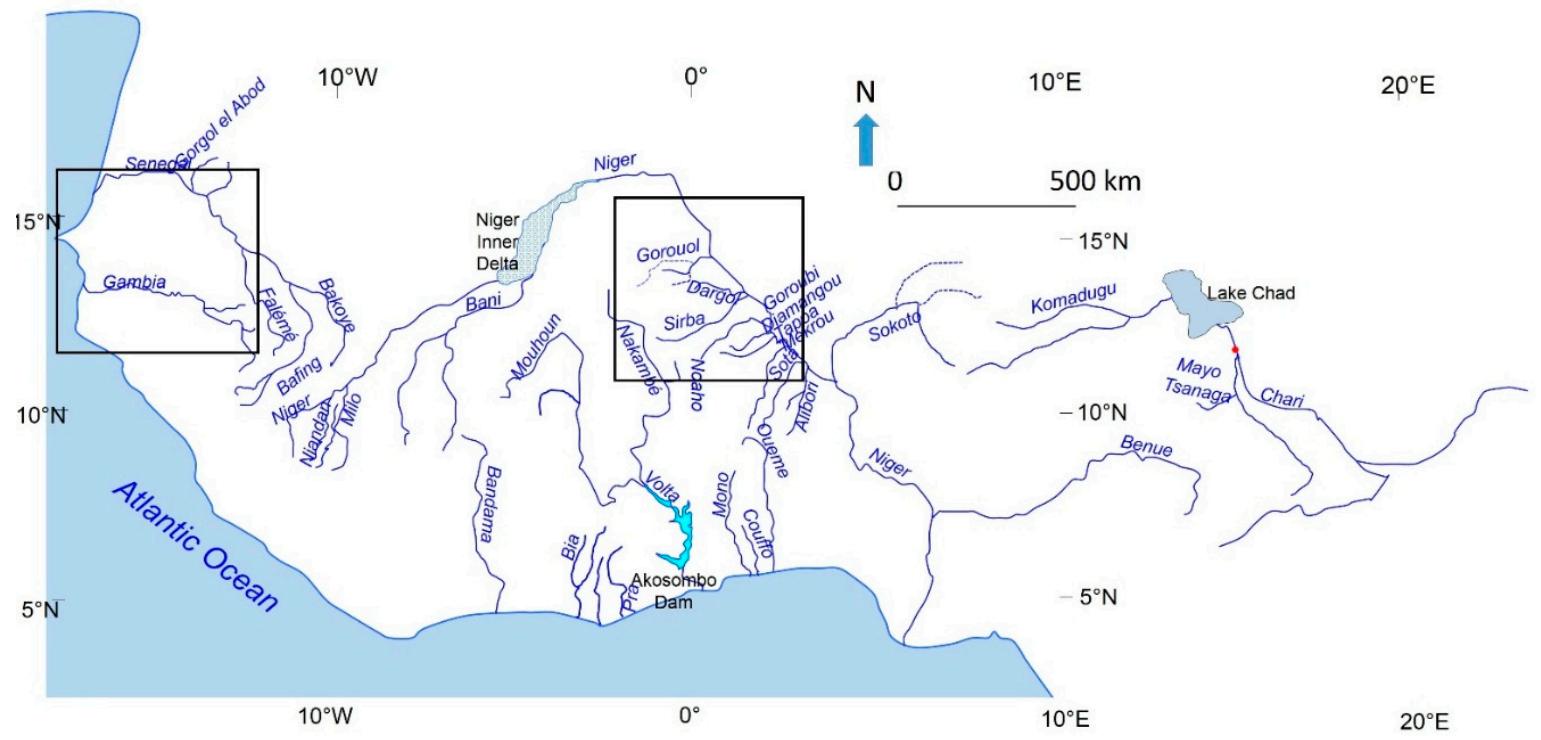

Figure 9. Location of the two areas cited in Figures 11-13: Senegambia (left square) and the Middle Niger River Basin (MNRB) (right square).

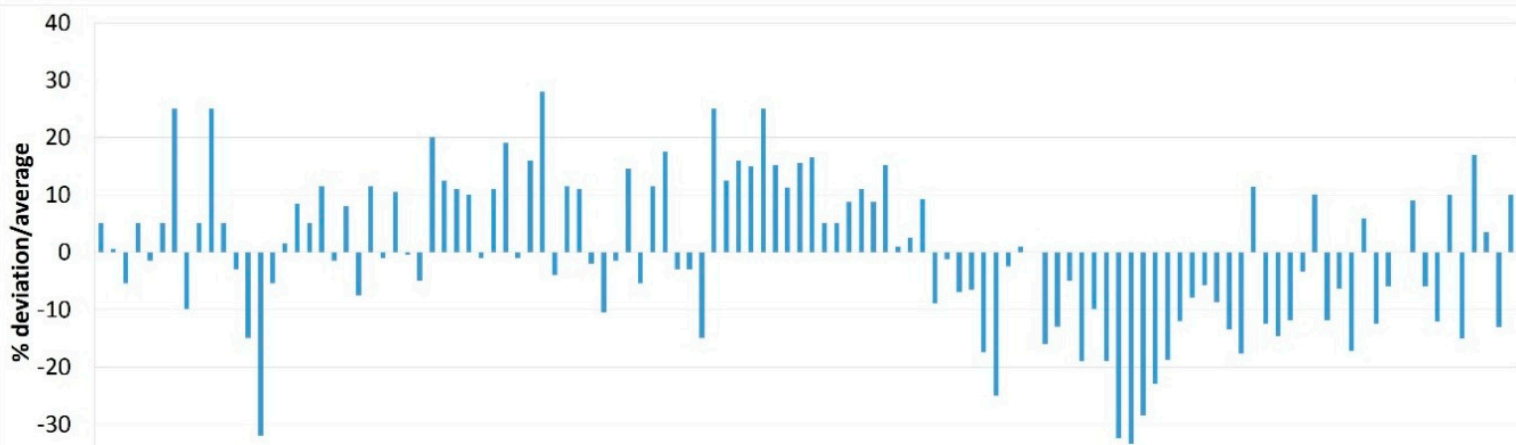

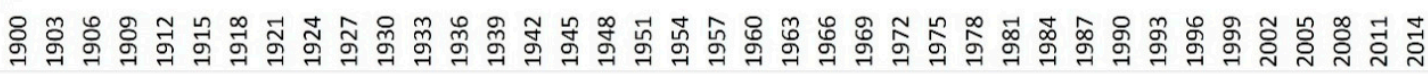

Figure 10. Evolution of annual rainfall index from 1900 to 2015 through the entire Niger River Basin delimited at Niamey station (approx. $700,000 \mathrm{~km}^{2}$, from $12^{\circ} \mathrm{W}$ to $3^{\circ} \mathrm{E}$ and from $8^{\circ}$ to $18^{\circ} \mathrm{N}$-see Figure 1a).

Descroix et al. [7] showed that in Senegambia, after a minimum at the beginning of the 1980s, the rainfall index has been increasing; in the MNRB, the minimum was recorded in 1985, and the index value increased strongly for 10 years and then remained stationary from 2003 at a median value that was lower than the mean of the total series. Therefore, the return to average rainfall values was delayed, but completed in Senegambia, while it was earlier, but not so marked in the MNRB. This weakening of rainfall recovery was also noticed by Badjana et al. [113] in northern Togo, where they showed that the interannual variability of annual precipitation is decreasing over the basin, with the average annual precipitation also decreasing. 
Figure 11a-f shows the evolution per decade of rainfall amount and number of rainy days; Figure 11a (Senegambia) and Figure 11b (MNRB) confirm the global evolution with a recovery of annual rainfall since the 2001-2010 decade in Senegambia, and since 1991-2000 in the MNRB. The number of rainy days (Figure 11c,d) followed the same evolution. However, in both cases, the number of rainy days decreased in the last, semi-decadal 2011-2015 period. Therefore, the rainfall amount per rainy day increased during this last period. It remains far from reaching its value during the wet period 1951-1970 in Senegambia (Figure 11e), while it reached it in MNRB for the 2001-2010 decade and exceeded it markedly during the last period (2011-2015) (Figure 11f). This last result is consistent with the observations made by Panthou et al. [4] in a larger area of the central Sahel, as well as with results from other regions of the Sahel and Africa [114,115].

\subsection{Extreme Events: An Intensification of Rainfall?}

There are not many studies of high-frequency rainfall intensity in the Sahel. Panthou et al. [4] analyzed its evolution from 1950 to 2010 in an extended central-Sahel area (from $4^{\circ} \mathrm{W}$ to $6^{\circ} \mathrm{E}$ and from $10^{\circ} \mathrm{S}$ to $15^{\circ} \mathrm{N}$ ). They first observed an increase in the extreme daily rainfall occurrence, in spite of a persisting deficit of the occurrence of rainfall; thus, the average intensity of the rainy events has increased.

These findings are partially consistent with those obtained for the two areas analyzed here, Senegambia and MNRB. The study summarized below considers the rainfall events of more than 60, 80 and $100 \mathrm{~mm}$ per day. In both areas, the 1981-1990 decade was characterized by the lowest number of events in these categories, and the lowest cumulated rainfall for these events (Figure 12). However, after a strong increase in both indicators (number of events and rainfall amount), during the 1991-2000 decade in Senegambia (Figure 12a) and during the following one in the MNRB (Figure 12b), the indicators reached a threshold, to be confirmed in future years.

However, in the case of Senegambia, as rainfall amount in the 2000-2015 period was far from that reached during the wet 1951-1970 period, the proportion of rain fallen in "heavy rainfall amount" events was significantly higher during the wet period. Conversely, in the MNRB, the number of events and total rainfall amount of these events did not reach the level of the wet 1951-1970 period. Therefore, there is no evidence in this area of an intensification of rainfall, except for daily events of more than $100 \mathrm{~mm}$ and for the sole 2001-2010 decade. This result does not completely match those of Panthou et al. [4]. Several reasons could explain this disagreement. First, our analysis was not performed over the same region; Panthou et al. [4] considered a larger area and a larger number of stations. In this study, we only consider 12 main rain gauges in the Sahelian area of the MNRB. Secondly, the analysis was realized using different methods. The one presented here was based on Thiessen-spatialized means of rainfall amount and number of events, and it was processed by decades and considered only daily events exceeding 60,80 and $100 \mathrm{~mm}$.

Daily maximum rainfall just reached values close to their maximum of the 1951-1967 period. This represents only a relative rainfall intensification. Effectively, the part of the total annual rain falling in extreme events increased. However, neither the number of extreme events, nor the rainfall amount of these events are higher than during the "wet" period. Consequently, they cannot explain the currently three- or four-fold increase in observed discharge and runoff coefficients compared with those of the 1951-1967 period in the MNRB.

However, the current period is characterized by changing conditions, such as:

- The current intensification contributes to the increase in runoff (accompanied by other factors);

- The intra-seasonal distribution of extreme events has likely changed, and should be analyzed further in future studies;

- An increase in maximal instant rainfall intensity and maximal rainfall at $5 \mathrm{~min}$ time step has been noticed in the very last few years [116]. 


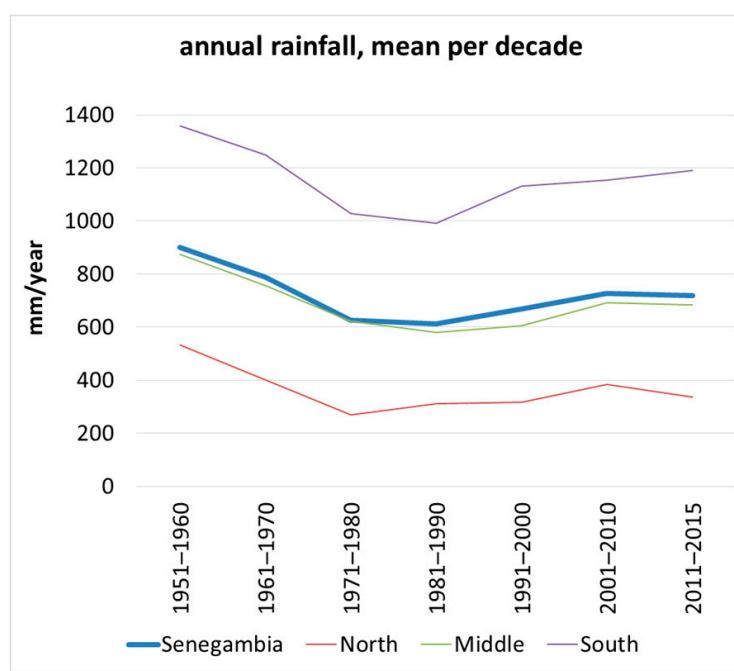

(a)

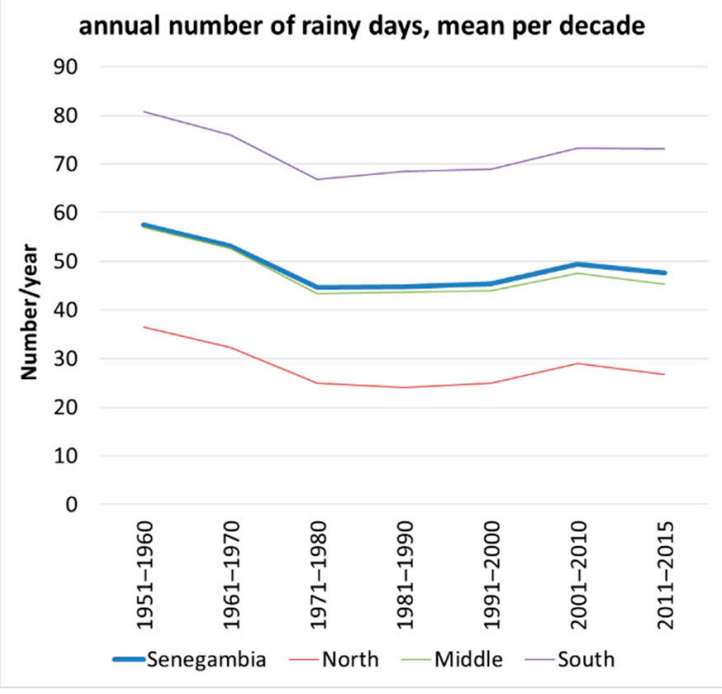

(c)

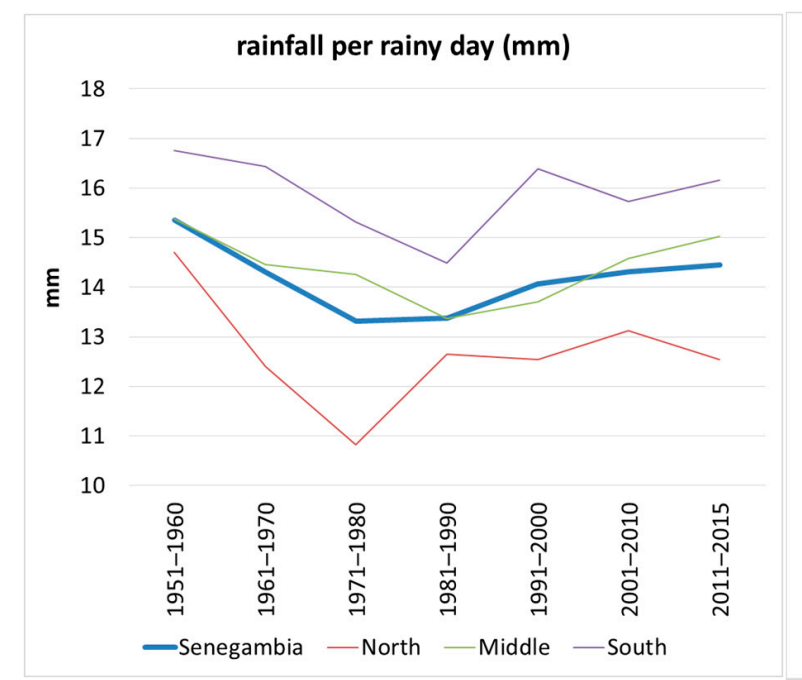

(e)

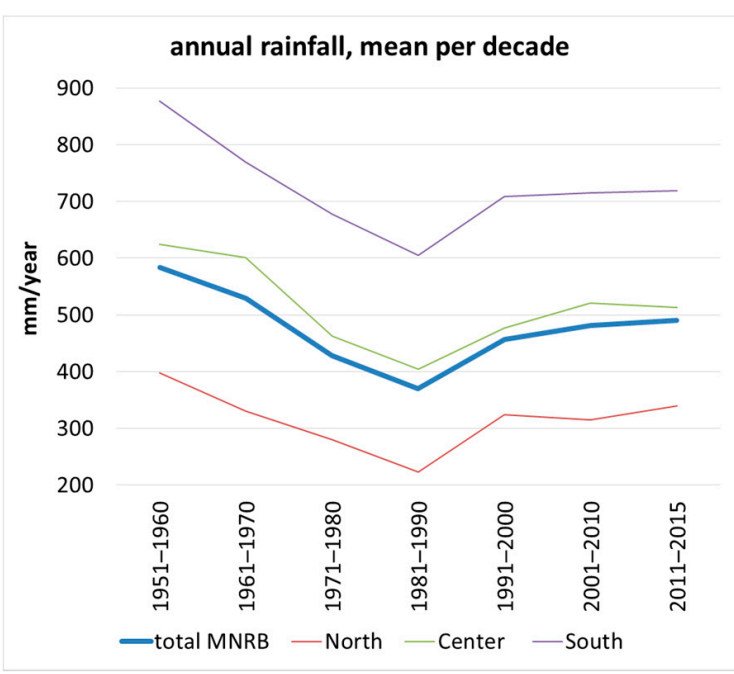

(b)

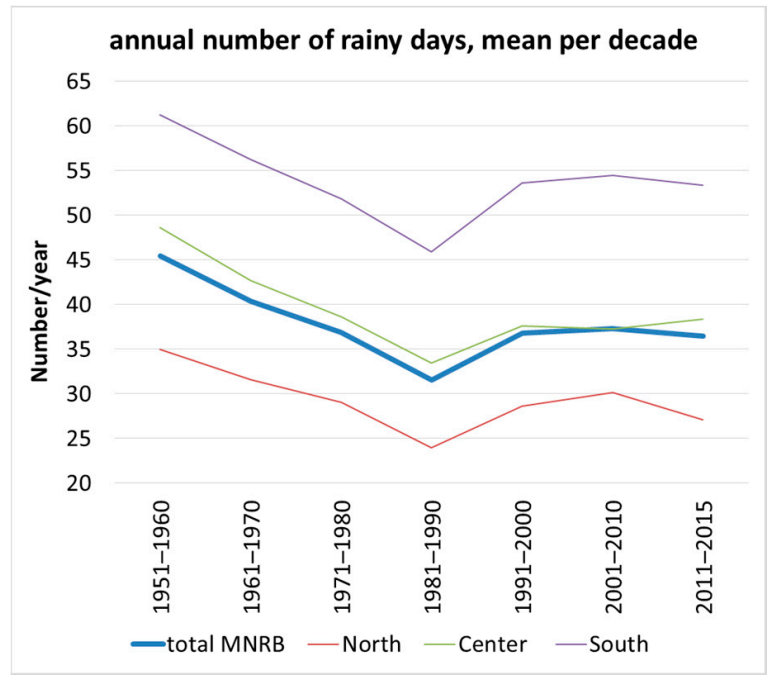

(d)

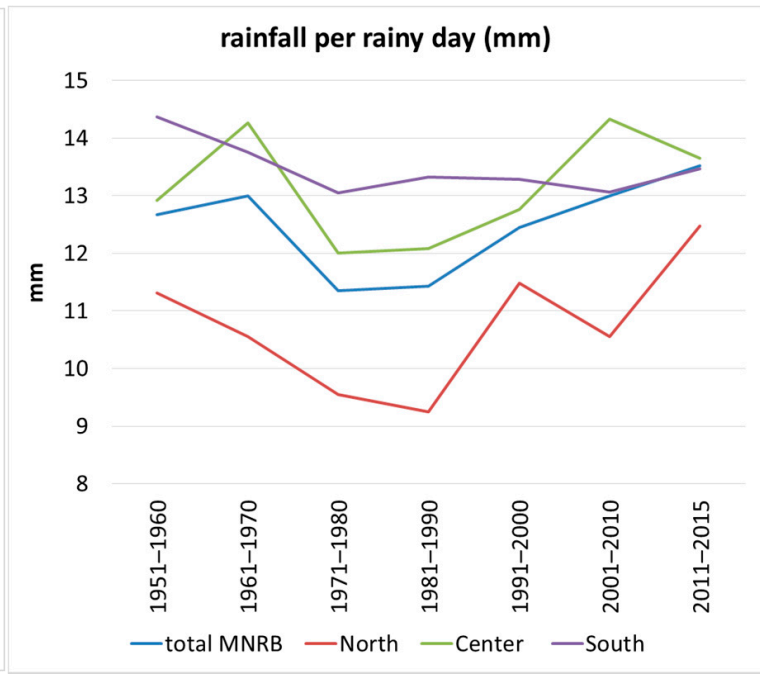

(f)

Figure 11. Decadal evolution of rainfall and number of events, and rainfall per event; data spatialized by Thiessen method; (a, c and e): Senegambia; (b, d and f): MNRB (see location in Figure 9). 
These observations could constitute the current trend, to be confirmed with new observations over the coming years.

Global warming leads to rainfall intensification; this could be associated with a modification of rain intra-seasonal distribution, and particularly of monsoon onset.

\subsection{The Onset of the Monsoon, through Agronomical Criteria}

Finally, after observing a recovery of "mean" rainfall amount [7,117], and an intensification of daily rainfall amount, it is worth analyzing the agronomical "quality" of the monsoon, which includes the temporal repartition of rainfall and the occurrence of dry periods. This has a direct impact on runoff, since a "good" spatio-temporal distribution of rainfall leads to improved vegetation cover, and then an improved soil WHC, regularizing the hydrological regime and functioning.

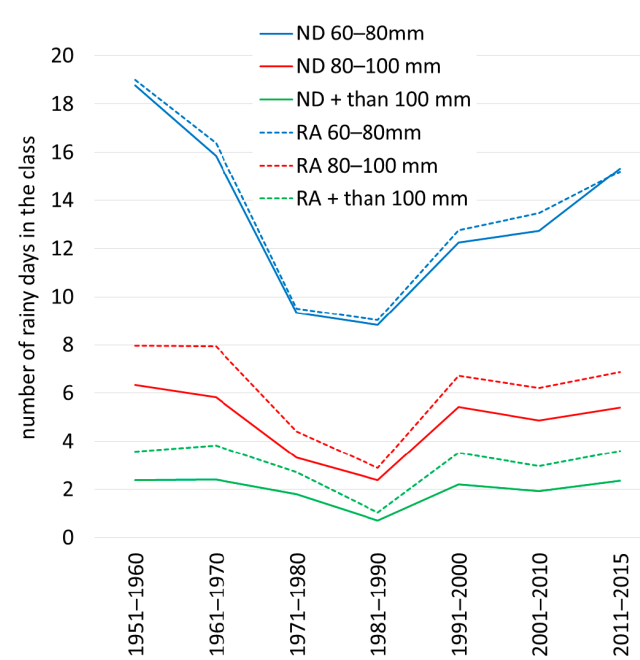

(a)

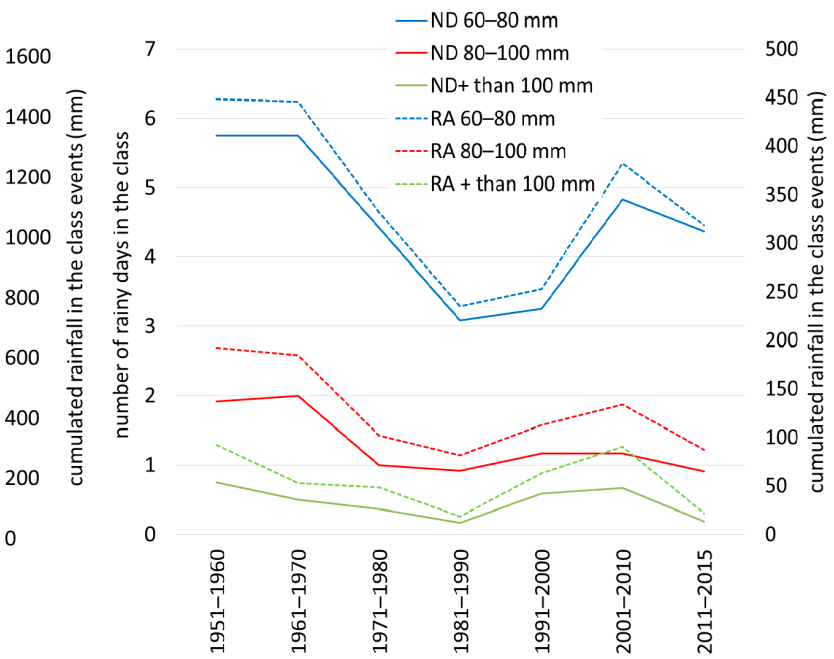

(b)

Figure 12. Decadal evolution of rainfall events above 60,80 and $100 \mathrm{~mm} \cdot$ day $^{-1}$ in Senegambia (a) and MNRB (b): number of rainy days (ND) and cumulated rainfall in each class (RA).

In order to synthesize the information about rain, we separated the rainy seasons into "good" and "bad" (or missed) monsoons, according to the criteria proposed by Sivakumar [118]: for each station, the rainy season cannot begin before 1 May, and the onset is effective when at least $20 \mathrm{~mm}$ of rainfall are observed in 3 days, without a dry period exceeding 7 days during the 30 following days (to avoid "false start").The end of the season occurs when 20 consecutive dry days are observed after 1 September.

Figure 13 gives the spatio-temporal occurrence of "missed" monsoons in Senegambia (top of the figure) and MNRB (bottom of the figure) from 1951 to 2015. Rainy seasons during which the Sivakumar criteria described above did not apply entirely are considered "missed". For the two areas, an increase in the number of "missed" monsoons is observed from 1972 to 1987. For the 1988-2015 period, Figure 13 shows a difference in regional behaviors: a clear decrease in the number of agronomically "missed" seasons is shown in Senegambia. In MNRB, after a marked decrease from 1987 to 1997, a return to bad rainy seasons is noticeable, largely during the 2000-2010 decade.

Finally, in research on the relative impact of human and natural factors, Aich et al. [93], observed both a general return to wet conditions since the end of the 1980s and an increase in annual maximum discharge in the NRB (Niger River Basin) for the same time period.

They estimated that the relationship between the climatic drivers and discharge is complex. They highlighted that it varies significantly between the regions because the changes in precipitation patterns in the region are very heterogeneous $[8,117]$. 


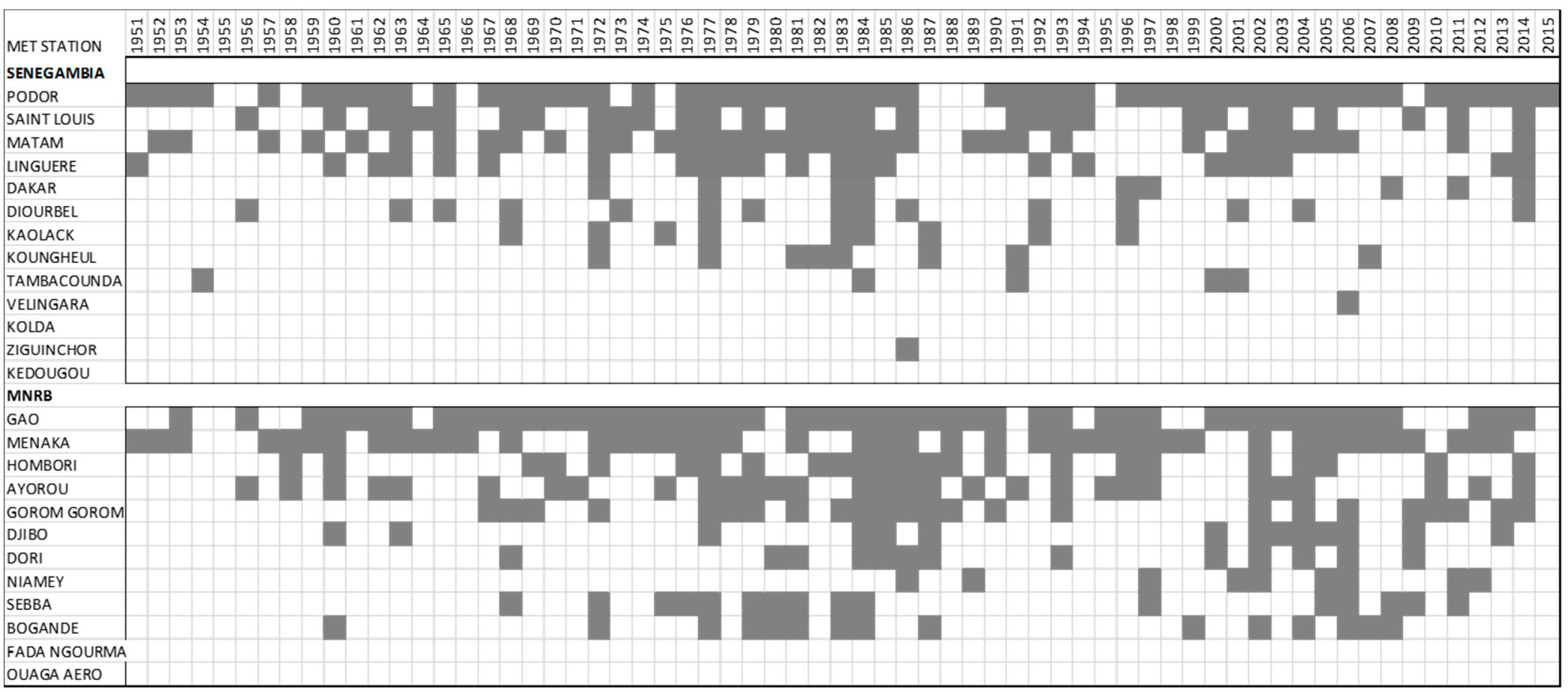

Figure 13. Spatio-temporal frequency of "missed" monsoons (black squares) in Senegambia (up) and Middle Niger River basin (bottom) from 1951 to 2015; in both areas, the stations are located in the table from the north to the south; "missed" according to the criteria defined by Sivakumar [116]: no event of more than 20 mm occurred that was not followed by a dry period longer than 7 days during the 1st month of the monsoon. 


\section{Conclusions and Perspectives}

This paper has reviewed the multidecadal evolution of hydrological processes in the Sahelian and Sudanian strips of West Africa, wherein an increase in flood occurrence has been observed since 1968 . More precisely, it focused on the respective roles of climate and LULCC in these changes.

After a humid 1950-1967 period, West Africa suffered a long rainfall deficit from 1968 to the 1990s. Since that decade, a rainfall recovery has been observed, and mean annual rainfall is now very close to the 1900-2015 long-term average. Despite the general re-greening that followed the Great Drought (1968-1990s), water does not infiltrate as efficiently as before. This concerns all soil types. At the same time, the annual rainfall recovery is associated with more flooding and inundations. Thus, from a hydrological point of view, the soil's rainfall use efficiency appears to have been declining. In other words, an edaphic drought has followed the climatic drought.

We presented an upscaling of hydrological behaviors based on the evolution of runoff coefficient before, during and after the dry West African 1968-1990s period. The recovery rate and duration are two of the main explanatory variables used to separate distinct evolutions. This upscaling made it possible to distinguish a Sahelian functioning from the Sudanian and the Guinean ones.

For Sahelian Rivers, the long-term trend has translated into a runoff coefficient that is nowadays up to 4 times higher than it was during the fifties and sixties (the wet period). This increase in runoff (associated with less rainfall) was noted during the Great Drought, and corresponds to the 1st Sahelian paradox. Since the 1990s, the rainfall amount has increased, but it is still lower than during that wet period (1951-1967).

The ongoing increase in runoff and discharge associated with a general re-greening during the three last decades is referred to the 'second Sahelian paradox' [13], as vegetation recovery hasn't led to an increase in soil WHC. Despite the recently observed extension of woody vegetation (Brandt et al.) [15], drought conditions have durably reduced the soil WHC. In addition, some small areas have witnessed a decrease in herbaceous and woody vegetation cover that has an important impact on soil erosion and surface runoff.

Finally, two types of aggravating factors of flooding can be identified:

- Urbanization throughout the whole Sudano-Sahelian strip, which exacerbates runoff coefficients;

- The net increase in extreme rainfall events, with severe consequences in rural and, more recently, in urban areas too.

Several studies have attempted to improve the understanding of the relationships between the observed runoff behaviors, LULCC and the increase of rainfall intensity [116]. They allow us to distinguish between two periods:

- The period of the 1st Sahelian Paradox (declining rainfall, increasing runoff and discharges), which is commonly attributed to LULCC, the decline of vegetation cover being due both to the severe rainfall deficit and associated woody vegetation dying, and to the increase in vegetation exploitation by a growing population (West Africa has had the highest demographic growth rate in the world since the 1980s);

- The period following the "Great Drought", which was characterized by a general vegetation re-greening (observed by remote sensing) and vegetal net primary productivity increase, as a rise in discharges of Sahelian rivers was occurring. The 2 nd Sahelian paradox (increase in runoff and increase in vegetation cover) is explained by both rainfall intensification and a reduction in soil WHC, probably linked to extension in cropping areas, as well as vegetation degradation and soil erosion over shallow soils $[20,26,38,39,53,76,77,80]$.

In order to improve our understanding of these paradoxes, it seems necessary:

- To increase the number of field and satellite observations of the basins, at different spatial scales, in order to document LULCC, associate processes and relevant variables; 
- To monitor the soil crusting processes and its spatial extension;

- To better understand, analyze and model urban hydrology, as urbanization progression in West Africa is also the highest in the world, mostly due to the low current urbanization rate;

- To improve the knowledge of the role of imperviousness and of drainage system;

- To implement adapted hydrological modelling accounting for these processes and adopting rigorous statistical attribution approaches, as suggested, e.g., by Merz et al. (2012) [119].

For the future, the IPCC 2013 [120] and IPCC 2017 [121] climate projections suggest an increase in rainfall in West Africa due to global warming, which would favor the dynamics of the monsoon, except in the western part of West Africa, where they suggest a dry period near the Atlantic Ocean in the near future (Biasutti [122] and Sultan [123]). However, the models are not accurate in their depiction of regional West African climates [124]. Some of their land-atmosphere simulated feedbacks even display the wrong sign [108]. Furthermore, in West Africa, the strong multi-decadal fluctuations of rainfall, which are influenced by oceanic circulations, are not well captured by these models. For instance, Ndehedehe et al. [125] showed significant correlation between the Atlantic Multi-decadal Oscillation (AMO) and the temporal evolution of standardized precipitation index (SPI). This result further corroborates the observed role of AMO-driven in terrestrial water storage (TWS) in the Sahel. It was also shown recently that interactions between climate, rural society and the environment drive land cover changes in the Sahel [126]. In particular, LULCC drives the distribution of rainfall water between infiltration, evaporation and runoff, and hence the water resources (Paturel et al. [126]). Thus, it appears necessary to make some significant progresses on the modelling of these processes, too, in order to be able to provide better information on future hydrology in West Africa.

Author Contributions: L.D., F.G., M.G. (Manuela Grippa) and L.A.L. coordinated and completed the redaction of the paper. L.K., L.G., P.H. and C.D. gathered, commented and criticized the rich bibliography on land use land cover changes, influence of crusting in pastoral areas, and wrote the synthesis of this item. Y.B. processed mappings and provided and prepared iconography. G.M. revised the whole paper and provided rich recommendations based on his great experience of Sahelian and Sudanian hydrology. G.P., G.Q., C.W., T.V., A.D.-N., O.N., Y.S., H.D., O.A., B.F., A.B. (Aliou Barry), A.B. (Alseny Barry), B.N.N. and J.-E.P. analyzed the data, commented, criticized and synthesized the abundant hydrological and climatological (rainfall!) data of the whole Sahel, and from the two parts where focus where needed to update the hydroclimatic knowledge of the Sahelo Sudanian strip (Senegambia and MNRB). T.P. (and F.G. again) wrote the chapter on land atmosphere feedbacks and the role of the surface on rain onset. B.S. revised the document and brought (and redacted!) new insights from an agronomical point of view; M.M.A., I.M. and J.-P.V. conceived, designed and performed the experiments on Ks and formation of crusting, and wrote the synthesis on the role of crusting in runoff coefficient; M.G. (Marielle Gosset) and C.C. contributed on the analysis tools on hydrological modelling in this region, and wrote the synthesis of this question.

Acknowledgments: We warmly acknowledge our colleagues of the Niger Basin Authority's "Projet Niger-Hycos" (NBA; http://nigerhycos.abn.ne/user-anon/htm/listStationByGroup.php) and the Niger Water Resources Department (DRE) for providing the Niger River discharge data. The Directors, and the colleagues of the Senegal (ANACIM), Burkina Faso, Mali and Niger Met Offices (Direction de la Météorologie Nationale) are also acknowledged. This work was partly funded by French ANR projects ECLIS (ANR-08-VULN-003-01 and ESCAPE (ANR-10-CEPL-005), as well as by the RHYVA project funded by FSP PARRAF of IRD. We also acknowledge the AMMA-CATCH observatory for its valuable data used here (mainly Fakara and Gourma sites).

Conflicts of Interest: The authors declare no conflict of interest.

\section{References}

1. Nicholson, S.E.; Tucker, C.J.; Ba, B. Desertification, drought and surface vegetation: An example from the West African Sahel. Bull. Am. Meteorol. Soc. 1998, 79, 815-829. [CrossRef]

2. Descroix, L.; Genthon, P.; Amogu, O.; Rajot, J.-L.; Sighomnou, D.; Vauclin, M. Change in Sahelian Rivers hydrograph: The case of recent red floods of the Niger River in the Niamey region. Glob. Planet. Chang. 2012, 98-99, 18-30. [CrossRef]

3. Nka, B.N.; Oudin, L.; Karambiri, H.; Paturel, J.-E.; Ribstein, P. Trends in floods in West Africa: Analysis based on 11 catchments in the region. Hydrol. Earth Syst. Sci. 2015, 19, 4707-4719. [CrossRef]

4. Panthou, G.; Vischel, T.; Lebel, T. Recent trends in the regime of extreme rainfall in the Central Sahel. Int. J. Climatol. 2014, 34, 3998-4006. [CrossRef] 
5. Taylor, C.M.; Belušić, D.; Guichard, F.; Parker, D.J.; Vischel, T.; Bock, O.; Harris, P.P.; Janicot, S.; Klien, C.; Panthou, G. Frequency of extreme Sahelian storms tripled since 1982 in satellite observations. Nature 2017, 544, 475-480. [CrossRef] [PubMed]

6. Descroix, L.; Bouzou Moussa, I.; Genthon, P.; Sighomnou, D.; Mahé, G.; Mamadou, I.; Vandervaere, J.-P.; Gautier, E.; Faran Maiga, O.; Rajot, J.-L.; et al. Impact of Drought and Land-Use Changes on Surface. Water Quality and Quantity: Chapter 10: The Sahelian Paradox; InTech: Zagreb, Croatie, 2013; pp. 243-271. [CrossRef]

7. Descroix, L.; Diongue Niang, A.; Panthou, G.; Bodian, A.; Sané, T.; Dacosta, H.; Malam Abdou, M.; Vandervaere, J.-P.; Quantin, G. Evolution récente de la mousson en Afrique de l'Ouest à travers deux fenêtres (Sénégambie et Bassin du Niger Moyen). Climatologie 2015, 12, 25-43. Available online: http: / / lodel.irevues.inist.fr/climatologie/ (accessed on 12 February 2018).

8. Ali, A.; Lebel, T. The Sahelian standardized rainfall index revisited. Int. J. Climatol. 2009, 29, $1705-1714$. [CrossRef]

9. Mahé, G.; Paturel, J.E. 1896-2006 Sahelian rainfall variability and runoff increase of Sahelian Rivers. C. R. Geosci. 2009, 341, 538-546. [CrossRef]

10. Anyamba, A.; Tucker, C.J. Analysis of Sahelian vegetation dynamics using NOAA-AVHRR NDVI data from 1981-2003. J. Arid Environ. 2005, 63, 59614. [CrossRef]

11. Prince, S.D.; Wessels, K.J.; Tucker, C.J.; Nicholson, S.E. Desertification in the Sahel: A reinterpretation of a reinterpretation. Glob. Chang. Biol. 2007, 13, 1308-1313. [CrossRef]

12. Fensholt, R.; Rasmussen, K. Analysis of trends in the Sahelian 'rain-use efficiency' using GIMMS NDVI, RFE and GPCP rainfall data. Remote Sens. Environ. 2011, 115, 438-451. [CrossRef]

13. Dardel, C.; Kergoat, L.; Hiernaux, P.; Grippa, M.; Mougin, E.; Ciais, P.; Nguyen, C.-C. Rain-Use-Efficiency: What it tells us about the Conflicting Sahel Greening and Sahelian Paradox. Remote Sens. 2014, 6, 3446-3474. [CrossRef]

14. San Emeterio, J.L. Désertification ou Reverdissement: Étude Multi-Scalaire de L'évolution du Couvert Végétal en Afrique Sahélienne à Partir de Données de Télédétection. Ph.D. Thesis, Université Paris Diderot, Paris, France, 12 December 2015.

15. Brandt, M.; Tappan, G.; Diouf, A.A.; Beye, G.; Mbow, C.; Fensholt, R. Woody Vegetation Die off and Regeneration in Response to Rainfall Variability in the West African Sahel. Remote Sens. 2017, 9, 39. [CrossRef]

16. Gal, L.; Grippa, M.; Hiernaux, P.; Pons, L.; Kergoat, L. The paradoxical evolution of runoff in the pastoral Sahel. Analysis of the hydrological changes over the Agoufou watershed (Mali) using the KINEROS-2 model. Hydrol. Earth Syst. Sci. 2017, 21, 4591-4613. [CrossRef]

17. Bacci, M.; Mouhaïmouni, M. Hazard Events Characterization in Tillaberi Region, Niger: Present and Future Projections. In Renewing Local Planning to Face Climate Change in the Tropics, Green Energy and Technology; Tiepolo, M., Pezzoli, A., Tarchiani, V., Eds.; Springer: Berlin, Germany, 2017; Chapter 3. [CrossRef]

18. Albergel, J. Sécheresse, désertification et ressources en eau de surface: Application aux petits bassins du Burkina Faso. In The Influence of Climate Change and Climatic Variability on the Hydrologic Regime and Water Resources; IAHS Publication: Wallingford, UK, 1987; pp. 355-365.

19. Mahé, G.; Leduc, C.; Amani, A.; Paturel, J.E.; Girard, S.; Servat, E.; Dezetter, A. Augmentation récente du ruissellement de surface en région soudano-sahélienne et impact sur les ressources en eau. In Hydrology of the Mediterranean and Semiarid Regions; Servat, E., Najem, W., Leduc, C., Ahmed, S., Eds.; IAHS Publication: Wallingford, UK, 2003; Volume 278, pp. 215-222.

20. Olivry, J.-C. Synthèse des Connaissances Hydrologiques et Potentiel en Ressources en Eau du Fleuve Niger; Provisional Report; World Bank, Niger Basin Authority: Niamey, Niger, 2002; 160p.

21. Bader, J.-C. Monographie Hydrologique du Fleuve Sénégal. IRD Editions. 2011. Available online: http:/ / horizon. documentation.ird.fr/exl-doc/pleins_textes/divers16-01/010065190.pdf (accessed on 27 November 2017).

22. Sakho, I.; Dupont, J.-P.; Cissé, M.T.; El Janyani, S.; Loum, S. Hydrological responses to rainfall variability and dam construction: A case study of the upper Senegal River basin. Environ. Earth Sci. 2017, 76, 253. [CrossRef]

23. SIEREM. Available online: http:/ / www.hydrosciences.fr/sierem/ (accessed on 23 February 2018).

24. Funk, C.; Peterson, P.; Landsfeld, M.; Pedreros, D.; Verdin, J.; Shukla, S.; Husak, G.; Rowland, J.; Harrison, L.; Hoell, A.; et al. The climate hazards infrared precipitation with stations-A new environmental record for monitoring extremes. Sci. Data 2015, 2, 150066. [CrossRef] [PubMed] 
25. Opoku-Ankomah, Y.; Amisigo, B.-A. Rainfall and runoff variability in the south western river system of Ghana. In Water Resources Variability in Africa during the XXth Century, Proceedings of the Abidjan'98 Conference, Abidjan, Côte d'lvoire, 8-11 November 1998; IAHS Publication: Wallingford, UK, 1998; pp. 307-314.

26. Mahé, G.; Lienou, G.; Descroix, L.; Bamba, L.; Paturel, J.-E.; Laraque, A.; Meddi, M.; Habaieb, M.; Adeaga, O.; Dieulin, C.; et al. The rivers of Africa: Witness of climate change and human impact on the environment. Hydrol. Process. 2013, 27, 2105-2114. [CrossRef]

27. Amoussou, E.; Camberlin, P.; Mahé, G. Impact de la variabilité climatique et du barrage Nangbéto sur l'hydrologie du système Mono-Couffo (Afrique de l'Ouest). Hydrol. Sci. J. 2012, 57, 805-817. [CrossRef]

28. Soro, T.D.; Djè, K.B.; Ahoussi, K.E.; Soro, G.; Kouassi, A.M.; Kouadio, K.E.; Oga, Y.M.-S.; Soro, N. Hydro climatologie et dynamique de l'occupation du sol du bassin versant du haut Bandama à Tortiya (nord de la Côte d'Ivoire). Vertigo 2012, 5, 23.

29. Dembélé, M.; Zwart, S.J. Evaluation and comparison of satellite-based rainfall products in Burkina Faso, West Africa. Int. J. Remote Sens. 2016, 37, 3995-4014. [CrossRef]

30. Katsanos, D.; Retalis, A.; Michaelides, S. Validation of a high-resolution precipitation database atabase (CHIRPS) over Cyprus for a 30-year period. Atmos. Res. 2016, 169, 459-464. [CrossRef]

31. Toté, C.; Patricio, D. Evaluation of Satellite Rainfall Estimates for Drought and Flood Monitoring in Mozambique. Remote Sens. 2015, 7, 1758-1776. [CrossRef]

32. Khronostat 1.01. 1995. Available online: http://www.hydrosciences.org/spip.php?article1000 (accessed on 15 September 2017).

33. Olsonn, L.; Eklundh, L.; Ardo, J. A recent greening of the Sahel, trends, patterns and potential causes. J. Arid Environ. 2005, 63, 55566. [CrossRef]

34. Herrmann, S.M.; Anyamba, A.; Tucker, C.J. Recent trends in vegetation dynamics in the African Sahel and their relationship to climate. Glob. Environ. Chang. 2005, 15, 394-404. [CrossRef]

35. Tschakert, P.; Sagoe, R.; Ofori-Darko, G.; Codjoe, S.M. Floods in the Sahel: An analysis of anomalies, memory, and participatory learning. Clim. Chang. 2010, 103, 471-502. [CrossRef]

36. Tarhule, A. Damaging rainfall and floodings: The other Sahel hazards. Clim. Chang. 2005, 72, $355-377$. [CrossRef]

37. Di Baldassare, G.; Montanari, A.; Lins, H.; Koutsoyiannis, D.; Brandimarte, L.; Blöschl, G. Flood fatalities in Africa: from diagnosis to mitigation. Geophys. Res. Lett. 2010, 37, L22402. [CrossRef]

38. Aich, V.; Koné, B.; Hattermann, F.F.; Paton, E.N. Time series analysis of floods across the Niger River Basin. Water 2016, 8, 165. [CrossRef]

39. Paeth, H.; Fink, A.H.; Poble, S.; Keis, F.; Mächel, H.; Samimi, C. Meteorological characteristics and potential causes of the 2007 flood in Sub-Saharan Africa. Int. J. Climatol. 2010, 31, 1908-1926. [CrossRef]

40. Lafore, J.-P.; Beucher, F.; Peyrillé, P.; Diongue_Niang, A.; Chapelon, N.; Bouniol, D.; Caniaux, G.; Favot, F.; Ferry, F.; Guichard, F.; et al. The extreme rain event of Ouagadougou in 2009 Part I: Multi-scale analysis and conceptual model. Q. J. R. Meteorol. Soc. 2017, 143, 3094-3109. [CrossRef]

41. Leblanc, M.; Favreau, G.; Massuel, S.; Tweed, S.; Loireau, M.; Cappelaere, B. Land clearance and hydrological change in the Sahel: SW Niger. Glob. Planet. Chang. 2008, 61, 49-62. [CrossRef]

42. Roudier, P.; Ducharne, A.; Feyen, L. Climate change impacts on runoff in West Africa: a review. Hydrol. Earth Syst. Sci. 2014, 18, 2789-2801. [CrossRef]

43. Mahé, G.; Olivry, J.C. Assessment of freshwater yields to the ocean along the intertropical Atlantic coast of Africa. C. R. l'Acad. Sci. 1999, 328, 621-626. [CrossRef]

44. Amani, A.; Nguetora, M. Evidence d'une modification du régime hydrologique du fleuve Niger à Niamey. In FRIEND 2002 Regional Hydrology: Bridging the Gap between Research and Practice, Proceedings of the Friend Conference, Cape Town, South Africa, 18-22 March 2002; Van Lannen, H., Demuth, S., Eds.; IAHS Publication: Wallingford, UK, 2002; pp. 449-456.

45. Mahé, G.; Paturel, J.E.; Servat, E.; Conway, D.; Dezetter, A. Impact of land use change on soil water holding capacity and river modelling of the Nakambe River in Burkina-Faso. J. Hydrol. 2005, 300, 33-43. [CrossRef]

46. Mahé, G.; Lienou, G.; Bamba, F.; Paturel, J.E.; Adeaga, O.; Descroix, L.; Mariko, A.; Olivry, J.C.; Sangaré, S.; Ogilvie, A.; et al. Le fleuve Niger et le changement climatique au cours des 100 dernières années. In Hydroclimatology Variability and Change, Proceedings of Symposium Held during IUGG, Melbourne, Australia, 22-25 July 2011; IAHS Publication: Wallingford, UK, 2011; Volume 344, pp. 131-137. 
47. El Vilaly, M.A.S.; El Vilaly, A.; Mahe, G. Characterizing 40-years of inter-regional migration in Southern Mauritania as a result of environmental changes. In Proceedings of the 19th EGU General Assembly, Vienna, Austria, 23-28 April 2017.

48. Gardelle, J.; Hiernaux, P.; Kergoat, L.; Grippa, M. Less rain, more water in ponds: a remote sensing study of the dynamics of surface waters from 1950 to present in pastoral Sahel (Gourma region, Mali). Hydrol. Earth Syst. Sci. 2010, 14, 309-324. [CrossRef]

49. Gal, L. Modélisation de L'évolution Paradoxale de L'hydrologie Sahélienne. Application au Bassin D'Agoufou (Mali). Ph.D. Thesis, Toulouse III-Paul Sabatier University, Laboratoire Géosciences Environnement, Toulouse, France, 2016.

50. Gal, L.; Grippa, M.; Hiernaux, P.; Peugeot, C.; Mougin, E.; Kergoat, L. Changes in lakes water volume and runoff over ungauged Sahelian watersheds. J. Hydrol. 2016, 540, 1176-1188. [CrossRef]

51. Descroix, L.; Mahé, G.; Lebel, T.; Favreau, G.; Galle, S.; Gautier, E.; Olivry, J.-C.; Albergel, J.; Amogu, O.; Cappelaere, B.; et al. Spatio-Temporal Variability of Hydrological Regimes around the Boundaries between Sahelian and Sudanian Areas of West Africa: A Synthesis. J. Hydrol. 2009, 375, 90-102. [CrossRef]

52. Paturel, J.-E.; Ouedraogo, M.; Servat, E.; Mahé, G.; Dezetter, A.; Boyer, J.F. The concept of hydropluviometric normal in West and central Africa in a context of climatic variability. Hydrol. Sci. J. 2003, 48, 125-137. [CrossRef]

53. Amani, A.; Paturel, J.-E. Le projet de révision des normes hydrologiques en Afrique de l'Ouest et Afrique Centrale. La Météorologie 2017. Available online: http://hdl.handle.net/2042/61964 (accessed on 22 February 2018). [CrossRef]

54. Cassé, C.; Gosset, M.; Vischel, T.; Quantin, G.; Tanimoun, B.A. Model-based study of the role of rainfall and land use-land cover in the changes in the occurrence and intensity of Niger red floods in Niamey between 1953 and 2012. Hydrol. Earth Syst. Sci. 2016, 20, 2841-2859. [CrossRef]

55. Zare, A.; Mahe, G.; Paturel, J.E.; Barbier, B. Influence du Bani sur la variabilité saisonnière et interannuelle de la crue du fleuve Niger dans le delta intérieur. J. Sci. Hydrol. 2017, 62, 2737-2752. [CrossRef]

56. Ibrahim, M.; Wisser, D.; Ali, A.; Diekkrüger, B.; Seidou, O.; Mariko, A.; Afouda, A. Water Balance Analysis over the Niger Inland Delta-Mali: Spatio-Temporal Dynamics of the Flooded Area and Water Losses. Hydrology 2017, 4, 40. [CrossRef]

57. Lemoalle, J.; Bader, J.-C.; Leblanc, M.; Sedick, A. Recent changes in Lake Chad: Observations, simulations and management options (1973-2011). Glob. Planet. Chang. 2012, 80-81, 247-254. [CrossRef]

58. Ngaressem, G.M.; Ngounou Ngatcha, B.; Raimond, C.; Issa, S. Le Développement du lac Tchad: Situation Actuelle et Futurs Possibles; Lemoalle, J., Magrin, G., Eds.; Development of Lake Chad: Current situation and possible outcomes; IRD: Marseille, France, 2014; 215p.

59. Badou, F.; Kapangawiziri, E.; Diekkrueger, B.; Hounkpe, J.; Afouda, A. Evaluation of recent hydro-climatic Changes in four tributaries of the Niger River basin (West Africa). Hydrol. Sci. J. 2016. [CrossRef]

60. Yira, Y. Modeling climate and land use change impacts on water resources in the Dano catchment (Burkina Faso, West Africa. Ph.D. Thesis, Bonn University, Germany, 2016.

61. Oguntunde, P.G.; Friesen, J.; Van de Giesen, N.; Savenije, H.H.G. Hydroclimatology of the Volta River Basin in West Africa: Trends and variability from 1901 to 2002. Phys. Chem. Earth 2006, 31, 1180-1188. [CrossRef]

62. Itiveh, K.O.; Bigg, G.O. The variation of discharge entering the Niger Delta system, 1951-2000, and estimates of change under global warming. Int. J. Climatol. 2008, 28, 659-666. [CrossRef]

63. Li, K.Y.; Coe, M.T.; Ramankutty, N.; De Jong, R. Modeling the hydrological impact of land-use change in West Africa. J. Hydrol. 2007, 337, 258-268. [CrossRef]

64. Bricquet, J.P.; Bamba, F.; Mahé, G.; Touré, M.; Olivry, J.C. Evolution récente des ressources en eau de l'Afrique atlantique. Revue des Sciences de l'Eau 1997, 10, 321-337. [CrossRef]

65. Orange, D.; Wesselink, A.; Mahé, G.; Feizouré, C. The effects of climate changes on river baseflow and aquifer storage in Central Africa. In Sustainability of Water Resources under Increasing Uncertainty, Proceedings of the 5th IAHS Assembly Rabat Symposium, Rabat, Morocco, 23 April-3 May 1997; IAHS Publication: Wallingford, UK, 1997; pp. 113-123.

66. Mahé, G. Surface/groundwater interaction in the Bani and Nakambé rivers, tributaries of the Niger and Volta basinsVolta basins. West Africa. Hydrol. Sci. J. 2009, 54, 704-712. [CrossRef] 
67. Amogu, O.; Descroix, L.; Yéro, K.S.; Le Breton, E.; Mamadou, I.; Ali, A.; Vischel, T.; Bader, J.-C.; Bouzou Moussa, I.B.; Gautier Boubkraoui, S.; et al. Increasing River Flows in the Sahel? Water 2010, 2, 170-199. [CrossRef]

68. Malam Abdou, M.; Vandervaere, J.-P.; Bouzou Moussa, I.; Faran Maiga, O.; Descroix, L. Compared hydrodynamic behaviour in sedimentary and crystalline sahelian contexts at the point, parcel and small catchment scales. In Geophysical Research Abstracts, Proceedings of the EGU General Assembly 2013, Vienna, Austria, 7-14 April 2013; Volume 15.

69. Mahé, G.; Olivry, J.C.; Dessouassi, R.; Orange, D.; Bamba, F.; Servat, E. Relations eaux de surface-Eaux souterraines d'une rivière tropicale au Mali. C. R. Acad. Sci. Paris 2000, 330, 689-692. [CrossRef]

70. Bouzou Moussa, I.; Faran Maiga, O.; Ambouta, J.M.K.; Sarr, B.; Descroix, L.; Adamou, M.M. Les conséquences géomorphologiques de l'occupation du sol et des changements climatiques dans un bassin-versant rural sahélien. Sécheresse 2009, 20, 145-152. [CrossRef]

71. Roudier, P.; Mahé, G. Calculation of design rainfall and runoff on the Bani basin (Mali): A study of the vulnerability of hydraulic structures and of the population since the drought. Hydrol. Sci. J. 2010, 55, 351-363. [CrossRef]

72. Descroix, L. Eau: Processus et Enjeux en Afrique de l'Ouest Sahélo-Soudanienne; Editions Archives Contemporaines; EAC: Paris, France, 2018.

73. Boserup, E. The Conditions of Agricultural Growth: The Economics of Agrarian Change under Population Pressure; Allen and Unwin: London, UK; Earthscan Publications: London, UK, 1993.

74. Tiffen, M.; Mortimore, M.; Gichuki, F. More People, Less Erosion: Environmental Recovery in Kenya; John Wiley \& Sons: London, UK, 1994; 311p.

75. Demont, M.; Jouve, P. Evolution D’agro-Systèmes Villageois Dans la Region de Korhogo (ord Côte d'Ivoire): Boserup vs. Malthus, Opposition ou Complémentarité? Dynamiques Agraires et Construction Sociale du Territoire. In Proceedings of the Séminaire CNEARC-UTM, Montpellier, France, 26-28 April 1999; pp. 93-108.

76. Souley Yéro, K.; Dessay, N.; Panthou, G.; Vischel, T.; Descroix, L. Evolution des Eaux de Surface et des Systèmes de Ruissellement à L'échelle de la Commune, Site Niger; ANR Program ESCAPE 2012; deliverable 1.7b; Unpublished work, 2012; 38p.

77. Ndiaye, B.; Esteves, M.; Vandervaere, J.P.; Lapetite, J.-M.; Vauclin, M. Effect of rainfall and tillage direction on the evolution of surface crusts, soil hydraulic properties and runoff generation for a sandy loam soil. J. Hydrol. 2005, 307, 294-311. [CrossRef]

78. Amogu, O.; Esteves, M.; Descroix, L.; Souley Yéro, K.; Rajot, J.-L.; Malam Abdou, M.; Boubkraoui, S.; Lapetite, J.M.; Dessay, N.; Zin, I.; et al. Runoff evolution according to land use change in a small Sahelian catchment. Hydrol. Sci. J. 2015, 60, 78-95. [CrossRef]

79. Prince, S.D.; Brown de Colstoun, E.; Kravitz, L. Evidence from rain-use efficiencies does not indicate extensive Sahelian desertification. Glob. Chang. Biol. 1998, 4, 359-374. [CrossRef]

80. Nicholson, S.E. On the question of the "recovery" of the rains in the West African Sahel. J. Arid Environ. 2005, 63, 615-641. [CrossRef]

81. Hein, L.; De Ridder, N. Desertification in the Sahel: A reinterpretation. Glob. Chang. Biol. 2006, 12, 751-758. [CrossRef]

82. Hountondji, Y.-C.; Ozer, P.; Nicolas, J. Mise en évidence des zones touchées par la désertification par télédétection à basse résolution au Niger. Cibergeo: Revue européenne de géographie 2004, 291. Available online: http:/ / hdl.handle.net/2268/3923 (accessed on 3 June 2018). [CrossRef]

83. Dardel, C.; Kergoat, L.; Hiernaux, P.; Mougin, E.; Grippa, M.; Tucker, C.J. Re-greening Sahel: 30 years of remote sensing data and field observations (Mali, Niger). Remote Sens. Environ. 2014, 140, 350-364. [CrossRef]

84. Hiernaux, P.; Ayantunde, A.; Kalilou, A.; Mougin, E.; Gérard, B.; Baup, F.; Grippa, M.; Djaby, B. Trends in productivity of crops, fallow and rangelands in Southwest Niger: Impact of land use, management and variable rainfall. J. Hydrol. 2009, 375, 65-77. [CrossRef]

85. Hiernaux, P.; Diarra, L.; Trichon, V.; Mougin, E.; Soumaguel, N.; Baup, F. Woody plant population dynamics in response to climate changes from 1984 to 2006 in Sahel (Gourma, Mali). J. Hydrol. 2009, 375, 103-113. [CrossRef]

86. Dardel, C.; Kergoat, L.; Hiernaux, P.; Grippa, M.; Mougin, E. Entre desertification et reverdissement du Sahel. Que se passe-t-il vraiment? In Les Sociétés Rurales Face aux Changements Climatiques et Environnementaux en Afrique de l'Ouest; Sultan, B., Lalou, R., Sanni, M.A., Oumarou, A., Soumaré, M.A., Eds.; IRD: Marseille, France, 2015; pp. 193-207; ISBN 978-2-7099-2146-6. 
87. Malam Abdou, M.; Vandervaere, J.-P.; Descroix, L.; Bouzou Moussa, I.; Faran Maiga, O.; Abdou, S.; Bodo Seyni, B.; Ousseini Daouda, M.L. Évolution de la conductivité hydraulique d'un sol sableux cultivé du Niger. Biotechnol. Agron. Soc. Environ. 2015, 19, 270-280.

88. Casenave, A.; Valentin, C. A runoff capability classification system based on surface feature criteria in semiarid areas of West Africa. J. Hydrol. 1992, 130, 231-249. [CrossRef]

89. Brandt, M.; Hiernaux, P.; Rasmussen, K.; Mbow, C.; Kergoat, L.; Tagesson, T.; Ibrahim, Y.Z.; Wélé, A.; Tucker, C.J.; Fensholt, R. Assessing woody vegetation trends in Sahelian drylands using MODIS based seasonal metrics. Remote Sens. Environ. 2016, 183, 215-225. [CrossRef]

90. Bamba, A.; Dieppois, B.; Konaré, A.; Pellarin, T.; Balogun, A.; Dessay, N.; Kamagaté, B.; Savané, I.; Diédhiou, A. Changes in Vegetation and Rainfall over West Africa during the Last Three Decades (1981-2010). Atmos. Clim Sci. 2015, 5, 367-379. [CrossRef]

91. Brandt, M.; Rasmussen, K.; Hiernaux, P.; Herrmann, S.; Tucker, C.J.; Tong, X.; Tian, F.; Mertz, O.; Kergoat, L.; Mbow, C.; et al. Reduction of tree cover in West African woodlands and promotion in semi-arid farmlands. Nat. Geosci. 2018, 11, 328-333. [CrossRef]

92. Trichon, V.; Hiernaux, P.; Walcker, R.; Mougin, E. The persistent decline of patterned woody vegetation: The tiger bush in the context of the regional Sahel greening trend. Glob. Chang. Biol. 2018, 24, 2633-2648. [CrossRef] [PubMed]

93. Aich, V.; Liersch, S.; Vetter, T.; Andersson, J.C.M.; Müller, E.N.; Hattermann, F.F. Climate or Land Use? Attribution of Changes in River Flooding in the Sahel Zone. Water 2015, 7, 2796-2820. [CrossRef]

94. Cassé, C.; Gosset, M.; Peugeot, C.; Pedinotti, V.; Boone, A.; Tanimoun, B.A.; Decharme, B. Potential of satellite rainfall products to predict Niger River flood events in Niamey. Atmos. Res. 2015, 163, 162-176. [CrossRef]

95. Descroix, L.; Mahé, G.; Olivry, J.-C.; Albergel, J.; Tanimoun, B.; Amadou, I.; Coulibaly, B.; Bouzou Moussa, I.; Faran Maiga, O.; Malam Abdou, M.; et al. Facteurs anthropiques et environnementaux de la recrudescence des inondations au Sahel. In Les Sociétés Rurales Face aux Changements Climatiques et Environnementaux en Afrique de l'Ouest; Sultan, B., Lalou, R., Sanni, M.A., Oumarou, A., Soumaré, M.A., Eds.; IRD: Marseille, France, 2015; pp. 153-170; ISBN 978-2-7099-2146-6.

96. Descroix, L.; Diedhiou, A. Etat des sols et évolution dans un contexte de changements climatiques. In $\mathrm{La}$ Grande Muraille Verte; IRD: Marseille, France, 2012; Chapter 3; 34p.

97. Boudet, G. Désertification de l'Afrique Tropicale sèche. Adansonia 1972, 12, 505-524.

98. Hiernaux, P.; Dardel, C.; Kergoat, L.; Mougin, E. Desertification, adaptation and resilience in the Sahel: Lessons from long term monitoring of agro-ecosystems. In The End of Desertification? Behnke, R.H., Mortimore, M., Eds.; Springer: Verlag Berlin Heidelberg, Germany, 2016; pp. 147-178. [CrossRef]

99. Descloitres, M.; Ribolzi, O.; Le Troquer, Y. Study of infiltration in a Sahelian gully erosion area using time-lapse resistivity mapping. Catena 2003, 53, 229-253. [CrossRef]

100. SIRENA. Available online: http:/ / www.pateo.ird.fr/recherche/sirena (accessed on 31 August 2017).

101. Moussa Issaka, A.; Somé, Y.S.C.; Abdourahmane Touré, A.; Hassane, B.; Malam Abdou, M.; Abba, B.; Garba, Z.; Yacouba, H. Spatial dynamic of mobile dunes, soil crusting and Yobe's bank retreat in the Niger's Lake Chad basin part: Cases of Issari and Bagara. Afr. J. Environ. Sci. Technol. 2016, 10, 104-110. [CrossRef]

102. Amogu, O. La Dégradation des Espaces Sahéliens et ses Conséquences sur L'alluvionnement du Fleuve Niger: Méthodes Expérimentales et Modélisation. Ph.D. Thesis, Université Joseph Fourier, Grenoble, France, 2009.

103. Le Breton, E. Réponses Hydrologiques et Géomorphologiques aux Changements Environnementaux au Sahel Nigérien. Ph.D. Thesis, University-Paris 1/University Abdou Moumouni of Niamey, Niger, 2012.

104. Mamadou, I.; Gautier, E.; Descroix, L.; Noma, I.; Bouzou Moussa, I.; Faran Maiga, O.; Genthon, P.; Amogu, O.; Malam Abdou, M.; et Vandervaere, J.-P. Exorheism growth as an explanation of increasing flooding in the Sahel. Catena 2015, 130, 131-139. [CrossRef]

105. Nicholson, S.E. The West African Sahel: A review of recent studies on the rainfall regime and its interannual variability. Hindawi Publ. Corp. ISRN Meteorol. 2013, 2013, 453521. [CrossRef]

106. Sanogo, S.; Fink, A.H.; Omotosho, J.A.; Ba, A.; Redl, R.; Ermert, V. Spatio-temporal characteristics of the recent rainfall recovery in West Africa. Int. J. Climatol. 2015, 35, 4589-4605. [CrossRef]

107. Zhang, W.; Brandt, M.; Guichard, F.; Tian, Q.; Fensholt, R. Using long-term daily satellite based rainfall data (1983-2015) to analyze spatio-temporal changes in the sahelian rainfall regime. J. Hydrol. 2017, 550, 427-440. [CrossRef] 
108. Taylor, C.M.; Gounou, A.; Guichard, F.; Harris, P.P.; Ellis, R.J.; Couvreux, F.; De Cauwe, M. Frequency of Sahelian storm initiation enhanced over meso-scale soil-moisture patterns. Nat. Geosci. 2011, 4, 430-433. [CrossRef]

109. Taylor, C.M.; De Jeu, R.A.M.; Guichard, F.; Harris, P.P.; Dorigo, W.A. Afternoon rain more likely over drier soils. Nature 2012, 489, 423-426. [CrossRef] [PubMed]

110. Pellarin, T. Apport de la Télédétection Spatiale de L’humidité du sol pour L'étude du Cycle de L'eau. Ph.D. Thesis, Université Grenoble-Alpes, Saint-Martin-d'Hères, France, 2016.

111. Sy, S.; Noblet-Ducoudré, N.D.; Quesada, B.; Sy, I.; Dieye, A.M.; Gaye, A.T.; Sultan, B. Land-Surface Characteristics and Climate in West Africa: Models' Biases and Impacts of Historical Anthropogenically-Induced Deforestation. Sustainability 2017, 9, 1917. [CrossRef]

112. Ozer, P.; Erpicum, M.; Demarée, G.; Vandiepenbeeck, M. The Sahelian drought may have ended during the 1990s. Hydrol. Sci. J. 2003, 48, 489-492. [CrossRef]

113. Badjana, H.M.; Renard, B.; Helmschrot, J.; Edjamé, K.S.; Afouda, A.; Wala, K. Bayesian trend analysis in annual rainfall total, duration and maximum in the Kara River basin (West Africa). J. Hydrol. Reg. Stud. 2017, 13, 255-273. [CrossRef]

114. New, M.; Hewitson, B.; Stephenson, D.B.; Tsiga, A.; Kruger, A.; Manhique, A.; Gomez, B.; Coelho, C.A.; Masisi, D.N.; Kululanga, E. Evidence of trends in daily climate extremes over southern and West Africa. J. Geophys. Res. 2006, 111, D14102. [CrossRef]

115. Frappart, F.; Hiernaux, P.; Guichard, F.; Mougin, E.; Kergoat, L.; Arjounin, M.; Lavenu, F.; Koité, M.; Paturel, J.-E.; Lebel, T. Rainfall regime across the Sahel band in the Gourma region, Mali. J. Hydrol. 2009, 375, 128-142. [CrossRef]

116. Panthou, G.; Lebel, T.; Vischel, T.; Quantin, G.; Sané, Y.; Ba, A.; Ndiaye, O.; Diongue-Niang, A.; Diop Kane, M. Rainfall intensification in tropical semi-arid regions: The Sahelian case. Environ. Res. Lett. 2018, 13, 064013. [CrossRef]

117. Vischel, T.; Lebel, T.; Panthou, G.; Quantin, G.; Rossi, A.; Martinet, M. Le retour d'une période humide au Sahel? Observations et perpectives. In Les Sociétés Rurales Face aux Changements Climatiques et Environnementaux en Afrique de l'Ouest; Sultan, B., Lalou, R., Sanni, M.A., Oumarou, A., Soumaré, M.A., Eds.; Ed IRD: Marseille, France, 2015; pp. 43-60; ISBN 978-2-7099-2146-6.

118. Sivakumar, M.V.K. Predicting rainy season potential from the onset of rains in southern Sahelian and Sudanian climatic zones of West Africa. Agric. For. Meteorol. 1988, 42, 295-305. [CrossRef]

119. Merz, B.; Vorogushyn, S.; Uhlemann, S.; Delgado, J.; Hundecha, Y. HESS Opinions “More efforts and scientific rigour are needed to attribute trends in flood time series". Hydrol. Earth Syst. Sci. 2012, 16, 1379-1387. [CrossRef]

120. IPCC, AR5. 2013. Available online: https://www.ipcc.ch/publications_and_data/publications_and_data_ reports.shtml (accessed on 12 May 2016).

121. IPCC 2017. Available online: https://www.ipcc.ch/pdf/press/PR_P46_Press_Conf_en.pdf (accessed on 8 December 2017).

122. Biasutti, M. Forced Sahel rainfall trends in the CMIP5 archive. J. Geophys. Res. Atmos. 2013, 118, 1613-1623. [CrossRef]

123. Sultan, B.; Guan, K.; Kouressy, M.; Biasutti, M.; Piani, C.; Hammer, G.L.; McLean, G.; Lobell, D.B. Robust features of future climate change impacts on sorghum yields in West Africa. Environ. Res. Lett. 2014, 9, 104006. [CrossRef]

124. Roehrig, R.; Bouniol, D.; Guichard, F.; Hourdin, F.; Redelsperger, J.-L. The present and future of the West African monsoon: A process-oriented assessment of CMIP5 simulations along the AMMA transect. J. Clim. 2013, 26, 6471-6505. [CrossRef]

125. Ndehedehe, C.E.; Awange, J.-L.; Kuhn, M.; Agutu, N.O.; Fukuda, Y. Climate teleconnections influence on West Africa's terrestrial water storage. Hydrol. Process. 2017, 31, 3206-3224. [CrossRef]

126. Paturel, J.-E.; Mahé, G.; Diello, P.; Barbier, B.; Dezetter, A.; Dieulin, C.; Karambiri, H.; Yacouba, H.; Maïga, A. Using land cover changes and demographic data to improve hydrological modeling in the Sahel. Hydrol. Process. 2016, 31, 811-824. [CrossRef]

(C) 2018 by the authors. Licensee MDPI, Basel, Switzerland. This article is an open access article distributed under the terms and conditions of the Creative Commons Attribution (CC BY) license (http:/ / creativecommons.org/licenses/by/4.0/). 